\title{
Tin ingots from a probable Bronze Age shipwreck off the coast of Salcombe, Devon: composition and microstructure
}

\author{
Quanyu Wang ${ }^{\mathrm{a}^{*}}$, Stanislav Strekopytov ${ }^{\mathrm{b}}$, Benjamin Roberts ${ }^{\mathrm{c}}$, Neil Wilkin ${ }^{\mathrm{d}}$
}

${ }^{a}$ Department of Conservation and Scientific Research, the British Museum, Great Russell Street, London WC1B 3DG, UK. Email: qwang@thebritishmuseum.ac.uk.

${ }^{\mathrm{b}}$ Department of Earth Sciences, Natural History Museum, Cromwell Road, London SW7 5BD, UK.

c Department of Archaeology, Durham University, South Road, Durham DH1 3LE, UK.

${ }^{\mathrm{d}}$ Department of Britain, Europe and Prehistory, the British Museum, Great Russell Street, London WC1B 3DG, UK.

\begin{abstract}
The seabed site of a probable Bronze Age shipwreck off the coast of Salcombe in southwest England was explored between 1977 and 2013. Nearly 400 objects including copper and tin ingots, bronze artefacts/fragments and gold ornaments were found. The Salcombe tin ingots provided a wonderful opportunity for the technical study of tin, which has been scarce. The chemical compositions of all the tin ingots were analysed using inductively coupled plasma mass spectrometry (ICP-MS) and inductively coupled plasma atomic emission spectroscopy (ICP-AES). Following the compositional analysis, microstructural study were carried out on eight Salcombe ingots selected to cover those with different sizes, shapes and variable impurity levels and also from the two Erme Estuary ingots using metallography and scanning electron microscopy coupled with energy dispersive X-ray spectrometry (SEMEDS). An extensive overview of archaeological tin in Europe is also provided.

All the Salcombe tin ingots analysed appeared to be quite pure with little variation in composition between them. Only two samples were found to contain over $0.1 \%$ iron and one contain over $0.1 \%$ copper. The compositions of the Salcombe tin ingots have been compared to the very few compositional analyses of tin objects found elsewhere such as the Late Bronze Age shipwreck of Uluburun but do not seem to have any connection between them. Further studies including lead and tin isotope analysis are needed to answer the question of provenance of the tin ingots, so as to contribute to the study of metal trading.
\end{abstract}


Keywords: tin ingots, Bronze Age, Salcombe, ICP-MS, trace elements

\section{Introduction}

The extraction and movement of tin throughout Europe and beyond during the Bronze Age (c. 2200-800 BC) has been investigated and discussed extensively for over a century (Baer, 1876; Dayton, 1971; Franklin et al., 1978; Muhly, 1985, 1993; Penhallurik, 1986; Pernicka, 1990, 1998; Pare, 2000; Giumlia-Mair and Lo Schiavo, 2003; Pigott, 2011). The 'tin trade' continues to play a key role in socio-economic models of Bronze Age societies in Europe and the Near East (Sherratt, 1993; Kristiansen and Larsson, 2005; Harding, 2013). This is due to the ubiquity of Bronze Age bronze objects across Europe and Asia, the highly unequal distribution of tin ore sources, and the fundamental importance of bronze objects to archaeological scholarship in analysing chronology, trade, warfare, craft production and ritual (Roberts and Thornton, 2014). The relative abundance of tin ore sources in Atlantic Europe, especially in southwest England, northwest France and Iberia as well as sources in Central Europe, especially the Erzgebirge mountains (spanning Germany and the Czech Republic), has consistently enticed archaeologists and archaeometallurgists. However, there are still no radiocarbon dated Bronze Age tin mines in Europe (Roden, 1985; Pernicka, 1998) in contrast to the extensive evidence for Bronze Age copper mining (O’Brien, 2014) and recent discoveries of Bronze Age tin mines at Kültepe, Turkey (Yener et al., 2015), Deh Hosein, Iran (Nezafati et al., 2009) and in east Kazakhstan (Stöllner et al., 2011). The archaeological evidence for potential sites of tin ore extraction relies upon associated Bronze Age material culture or settlement activity as at San Cristóbal de Logrosán, Spain (Merideth, 1998; Rodríguez Díaz et al., 2013) and Mt. Cer, Serbia (Huska et al., 2014). The use of trace element data as well as lead and tin isotope compositions provide insights into the provenance and can be especially useful in excluding potential tin sources, as demonstrated by the continued absence of any evidence for Bronze Age tin extraction in the Erzgebirge mountains (Niederschlag et al., 2003; Haustein et al., 2010). The evidence for Bronze Age tin smelting sites in Europe remains restricted to several fragmentary finds of tin smelting slags although this is potentially due to the purity of the tin ores (Muhly, 1985; Malham, 2010). There have been discoveries of Bronze Age tin ingots in the east Mediterranean, and especially at shipwreck sites such as Uluburun at the southern coast of Anatolia (Pulak, 2000a; Hauptmann et al., 2002; Pulak, 2010), Cape Gelidonya (Bass, 1967, 2010) and Haifa (Stos-Gale et al., 1998). However, recent surveys of Bronze Age tin objects - as opposed to tin used in metal alloys or tin used as an inlay in other materials - across the rest of Europe 
have collectively recorded less than 300 objects with the vast majority being small beads, pendants and other ornaments. However, this striking lack of Bronze Age tin objects could be primarily due to the corrosion of tin metal to tin oxide powder, especially in buried terrestrial environments (Turgoose, 1985), but to a lesser degree in submarine seawater environments (Memet, 2014). Hence, whilst there are numerous publications on the Bronze Age mining and trade of tin, technical studies of tin objects are still relatively rare (Hauptmann et al., 2002; Stos-Gale et. al., 1998; Valera and Valera, 2003; Cahill, 2009; Lo Schiavo et al., 2009; Haustein et al., 2010; Krüger et al., 2012; Nielsen, 2014).

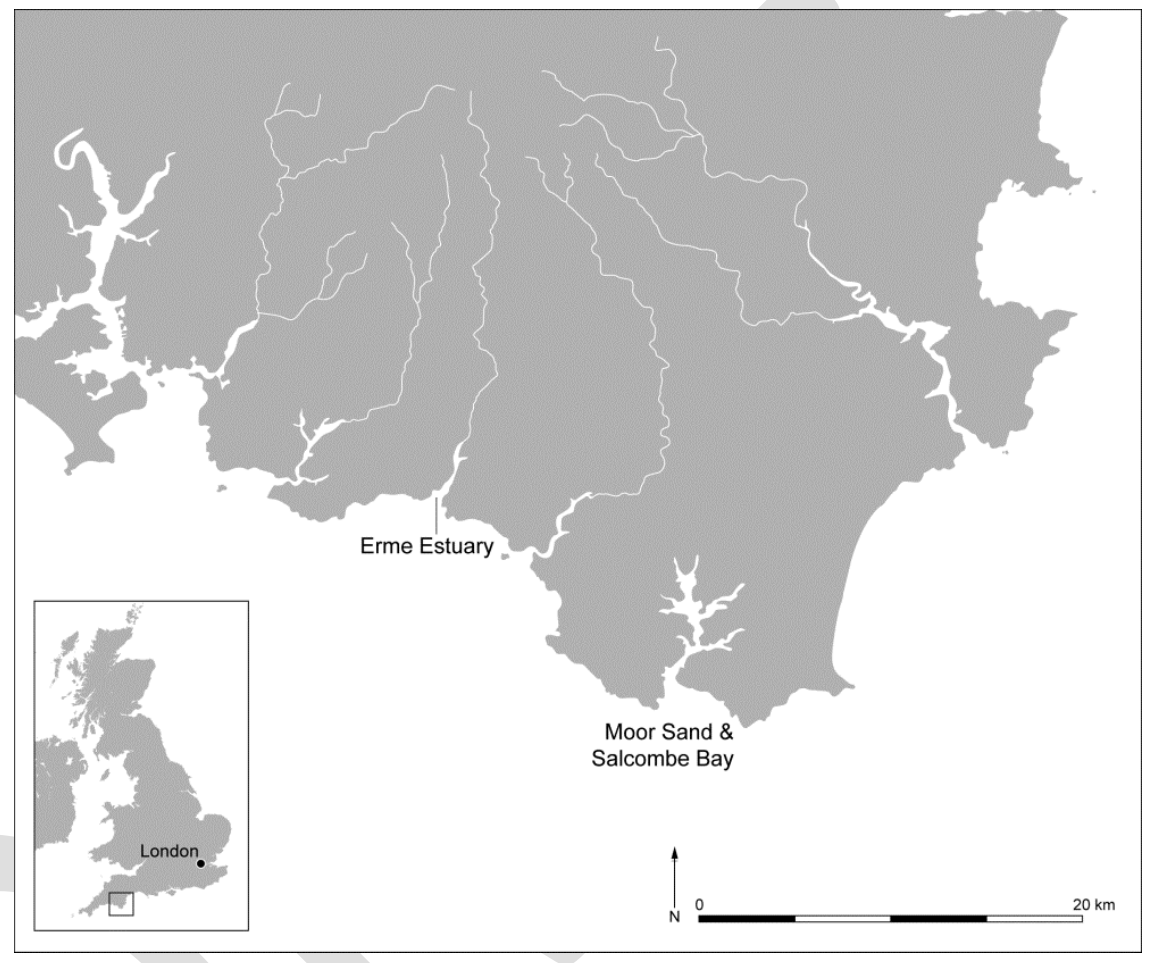

Fig. 1. The Salcombe site (redrawn by Craig Williams, British Museum after Needham et al. 2013, fig. 1.10).

The Salcombe site actually comprises two named sites $400 \mathrm{~m}$ apart within an open bay at the mouth of an estuary - Moor Sand and Salcombe B - where two groups of Bronze Age objects have been found between 50 and $400 \mathrm{~m}$ off the coastline (Fig. 1). Archaeological work at Moor Sand occurred between 1977 and 1982, led by Philip Baker and Keith Muckelroy (Muckelroy, 1980, 1981), whilst work on Salcombe site B started in 2004 by the South West Maritime Archaeology Group (www.swmag.org) and remains ongoing. The early excavations (1977-2004) at the Salcombe (Moor Sand and Salcombe site B) have been recently published with extensive environmental, archaeometallurgical and archaeological analyses. They recovered 31 objects including bronze objects of 22 weapons/fragments, one palstave-adze, one cauldron handle, one rectangular block/weight, one Sicilian strumento con 
immanicatura a cannone, three gold objects/fragments, an iron awl with a bone handle and a tin lump (Needham et al., 2013). In the absence of surviving organic material suitable for radiocarbon dating, detailed typo-chronological analyses of diagnostic bronze and gold objects, supported by radiocarbon dates from terrestrial sites containing comparable metalwork, placed the Salcombe assemblage in the Middle Bronze Age Penard metalwork phase (c. 1300-1150 BC) with the exception of one Type Nantes bronze sword which typologically dated to the Late Bronze Age Ewart Park metalwork phase (c. 1000-800 BC) (Needham and Giardino, 2008; Needham et al., 2013; Brandherm and Moskal-del Hoyo, 2014). Compositional analysis revealed that the bronzes were consistent with this dating as well as a high level of purity in the tin lump (Northover, 2013). The analysis of the sea level history and coastal geomorphology demonstrates that coastal retreat cannot explain the distribution of the metalwork and it is therefore argued that the objects were transported to their location before being dispersed on the seabed (Needham et al., 2013). The prevalence of later shipwrecks - Salcombe B was only found due to the investigation of a $17^{\text {th }}$ century AD shipwreck site termed Salcombe A - makes an accidental shipwreck or deliberate/votive shipwreck with objects eventually dispersed across the Moor Sand and Salcombe B sites. However, the presence of Bronze Age metalwork which is conventionally dated two centuries apart also implies two distinct events (Needham et al., 2013).

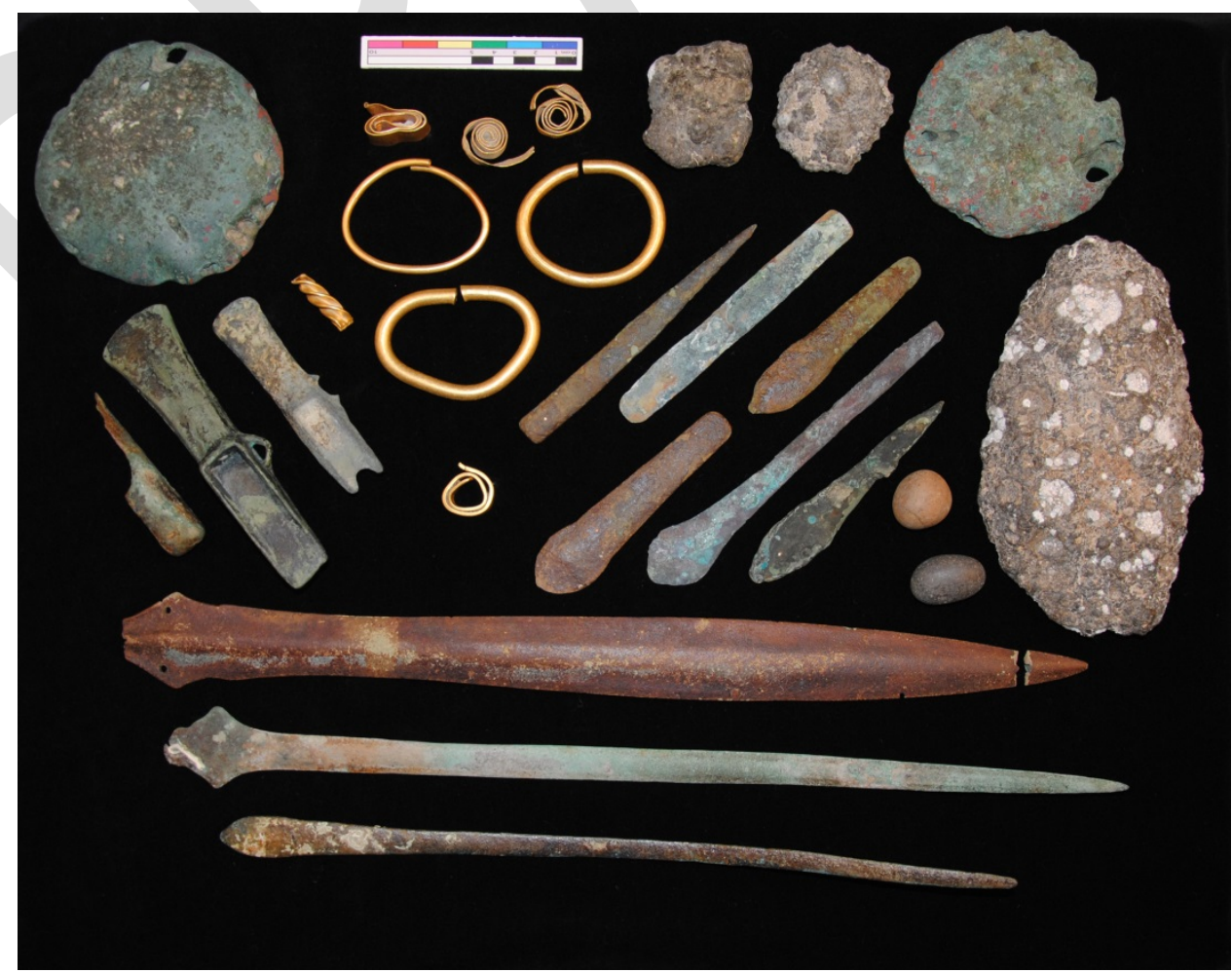

Fig. 2. Metalwork finds of 2005-2009 from Salcombe. 
The 2005-2013 finds include 280 copper or copper alloy and 40 tin bun-shaped ingots, 15 bronze objects and nine gold ornaments (Fig. 2). The tin ingots are the subject of this paper whilst the copper/copper alloy ingots, the gold ornaments and the bronze tools and weapons will be studied in subsequent papers. All finds have been acquired by the British Museum, are registered and have been catalogued on Collections Online (http://www.britishmuseum.org/research/collection_online/search.aspx?searchText=Salcombe).

Due to their extreme rarity and morphological simplicity, the tin ingots are not typologically diagnostic and, whilst they are more common, neither are the copper/copper alloy ingots (Bachmann et al., 2004). The bronze rapiers and palstaves as well as the gold twisted torc fragments and twisted wire bracelets all indicate a Middle Bronze Age Penard phase (c. 1300-1150 BC) date (see Collections online). However, the Ewart Park type bronze sword can only be placed in the Late Bronze Age Ewart Park phase (c. 1000-800 BC). The rarity of any terrestrial metal ingots in southwest England during the earlier date range, as opposed to their relative ubiquity in the later date range (see Pearce, 1983; Knight et al., 2015 for a comprehensive Bronze Age metalwork catalogue for southwest England), is not sufficient grounds to propose a finer temporal resolution for the tin ingots. Hence, whilst the tin ingots have an overall date range of c. 1300-800 BC, they could either be c. 1300-1150 BC or c. 1000-800 BC based upon the typo-chronology of the two groups of potentially associated bronze and gold metal objects.

The Salcombe tin ingots provide a very rare opportunity to analyse directly the Bronze Age 'tin trade'. The tin ingots vary in size and weight as well as in shape although they are generally bun-shaped and most of them are original in size and complete (Table 1). The surface of these ingots is bumpy and covered with corrosion products. Compositional analysis was carried out on all but one of the Salcombe ingots (2013,8032.5 which appeared to have completely corroded), i.e., a total of 39 pieces. Two morphologically comparable tin ingots of the 44 found by the South West Maritime Archaeology Group in the Erme Estuary also known as Bigbury Bay (Fox, 1995, 1996) - were donated to the British Museum and analysed for comparison. Following the compositional analysis, metallurgical samples were taken from eight Salcombe ingots to cover those with different sizes, shapes and variable impurity levels and also from the two Erme Estuary ingots for microstructural study. The present study is the first insight into the pattern of trace and ultra-trace impurities in ancient tin ingots employing a very sensitive analytical technique (inductively coupled plasma mass spectrometry; ICP-MS) combined with metallographic study. This paper will investigate: the purity of the tin; whether there is significant variation in the composition between the ingots; 
and whether the compositions connect them to any analysed tin samples found elsewhere. It will also place the tin ingots from Salcombe within the context of current evidence relating to Bronze Age tin production and movement in Europe. The difficult question of provenance will be addressed using lead and tin isotope analysis (cf. Haustein et al., 2010) in a future study.

\section{Experimental}

\subsection{Sampling}

A sample of around $20 \mathrm{mg}$ was taken from each ingot by drilling using a $1 \mathrm{~mm}$ high speed steel drill bit. To obtain uncorroded interior sample of metal for a reliable determination of the alloy composition, the drillings of the corroded surface were discarded until shiny metal turnings appeared. Tin is very soft, which made the drilling very difficult. Thicker areas appeared to be corrosion 'warts'; therefore, most drillings were taken from the sides of the ingots at thinner areas. The discarded drillings were saved for X-ray diffraction (XRD) analysis to identify the surface corrosion products.

\subsection{ICP-MS and ICP-AES procedure}

The alloy composition was determined using ICP-MS and inductively coupled plasma atomic emission spectroscopy (ICP-AES) at the Natural History Museum, London using an Agilent 7700x ICP mass spectrometer and Thermo Scientific iCap 6500 Duo ICP spectrometer, respectively. The samples (4-25 mg) were weighed to $\pm 0.01 \mathrm{mg}$, digested in 1 $\mathrm{ml}$ of concentrated $\mathrm{HCl}\left(\mathrm{SpA}^{\mathrm{TM}}\right.$ grade, ROMIL Ltd) with the addition of several drops of $\mathrm{HNO}_{3}\left(\mathrm{SpA}^{\mathrm{TM}}\right.$ grade, ROMIL Ltd) and $\mathrm{H}_{2} \mathrm{O}_{2}$ (Merck, Suprapur ${ }^{\circledR}$ ), and made up to $25 \mathrm{ml}$ with ultra-pure water. Only tin (Sn) and sulphur (S) concentrations are reported based on the ICPAES analysis, the rest of the elements were determined by ICP-MS. Based on the analysis of tin in CRMs (Tin with impurities; MBH Analytical Ltd) the analytical accuracy for tin (Sn) is within $0.6 \%$ (relative), for iron $(\mathrm{Fe})-3 \%$, nickel $(\mathrm{Ni})-7 \%$, copper $(\mathrm{Cu})-2 \%$, zinc $(\mathrm{Zn})-$ 3\%; arsenic (As), silver (Ag), indium(In), lead (Pb), bismuth (Bi) - 1\%, antimony (Sb) - 2\% and gold $(\mathrm{Au})-13 \%$.

\subsection{Metallography}

Following the compositional analysis, metallurgical samples were taken from Salcombe ingots 2010,8032.297, 302, 306, 308, 310, 311, 313 and 323 in an attempt to cover ingots 
with different sizes, shapes and variable impurity levels, and also from the two Erme Estuary ingots recently donated to the British Museum (2013,8031.1 \& 2).

The metallographic samples were taken using an Isomet diamond saw. The sections were mounted in epoxy resin, ground and then polished using diamond paste to a finish of $1 \mu \mathrm{m}$. Scanning electron microscopy coupled with energy dispersive X-ray spectrometry (SEMEDS) was used for the study of inclusions in the metals as well as the surface corrosion layers. The SEM-EDS analysis was carried out using a Hitachi S-3700N Variable Pressure SEM with an Oxford INCA Energy system, running at an accelerating voltage of $20 \mathrm{kV}$ at low vacuum (50 Pa) with a working distance of $10 \mathrm{~mm}$. After examination of the inclusions, the polished sections were etched using nital (2\% nitric acid in $100 \mathrm{ml}$ ethanol) in an attempt to reveal the metallographic structure of the metals.

\section{Results}

\subsection{Chemical composition}

The ICP-MS analyses (Table 2) show that all the tin ingots analysed are unalloyed tin with very low levels of impurities, typical of most of the early tin ingots as claimed by Tylecote (1986). The low total for some of the samples may be due to corrosion products present in the samples, as also seen in some of the metallurgical sections taken from the ingots. Archaeological tin finds are rare and compositional analysis of them is even rarer. Thirty two Uluburun tin ingots analysed by ICP-AES showed they were also quite pure (Hauptmann et al., 2002). A few tin ingots at Hishuley Carmel and Kfar Samir from underwater off the coast of Israel analysed by Begemann et al. (1999) and three Bronze Age tin torcs from Kilsallagh, Co. Longford of Ireland analysed by Cahill (2009) also showed very pure tin. During the excavations at the bank of Lake Sevan, Armenia many tincontaining objects dated 1400-1200 BC were found, of which 14 were subjected to spectral analysis. While some of the objects are reported to be alloys of tin and lead, five out of seven analysed tin buttons are relatively pure tin $(0.01-0.35 \% \mathrm{~Pb}$ and $0.03-0.25 \%$ Fe being the major impurities) (Kashkay and Selimkhanov, 1973; Selimkhanov, 1978). Two tin ingots from Bigbury Bay, South Devon were reported to have been analysed using electron probe micro analysis (EPMA) and revealed that both are of about 99\% purity (Fox, 1995). However, the data of the Bigbury tin ingots cannot be compared with the Salcombe analysis reported here, because 1) the date of the Bigbury tin ingots could range from the British Iron Age to the post-Roman epoch: 500 BC - AD 600 (Fox, 1995, 1996); and 2) the EMPA data is not directly comparable with the bulk analysis such as solution-based ICP-MS analysis. For 
the purpose of comparison between the tin ingots from different sites one Uluburun ingot (KW3935) containing unusually high amount of antimony (0.15\%) and silver (0.024\%) relative to other Uluburun tin ingots is excluded from all calculations, thus from histograms of trace element concentrations (Fig. 3).

\subsection{Impurity patterns}

\subsubsection{Iron}

Iron is present at low levels in the Salcombe ingots with a median concentration being $100 \mu \mathrm{g} \mathrm{g}^{-1}$ and $87 \%$ of the ingots contain iron at concentrations below $500 \mu \mathrm{g} \mathrm{g}^{-1}$. Iron concentration in Uluburun ingots is generally lower than in the Salcombe ingots with the distribution being shifted to lower level (median is $55 \mu \mathrm{g} \mathrm{g}^{-1}$ ). While only one Erme Estuary ingot out of two analysed in this study contains higher iron (2065 $\mu \mathrm{g} \mathrm{g}^{-1}$ ), three more ingots from this site were previously analysed by Craddock and Hook (1993) using ICP-AES and reported to contain $0.136,0.40$ and $1.07 \%$ iron, respectively, which are significantly higher than that of the Salcombe ingots (Fig. 3a).

\subsubsection{Lead}

The Salcombe and Erme Estuary ingots have very low lead levels, with $90 \%$ of the Salcombe ingots being lower than $40 \mu \mathrm{g} \mathrm{g}^{-1}$ (Table 2). This is consistent with the lead contents of three tin objects from Flag Fen, England and two unalloyed tin objects from

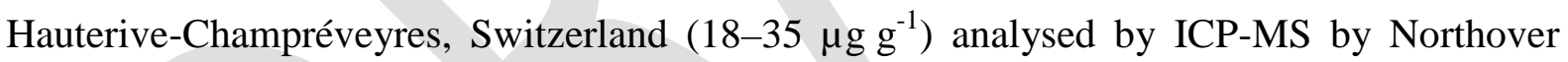
and Gillis (1999). On the other hand, even though a median concentration for lead in Uluburun tin ingots is estimated to be as low as $70 \mu \mathrm{g} \mathrm{g}^{-1}$, about a third of them contain lead at concentrations above $500 \mu \mathrm{gg}^{-1}$ (up to 0.26\%) (Fig. 3b), perhaps more resembling Armenian unalloyed tin objects (Kashkay and Selimkhanov, 1973) than European finds. Recent study of Bronze Age tin rings (speculated to have functioned as ingots) from the Tollense valley in northeastern Germany by micro X-ray fluorescence ( $\mu$-XRF) (Krüger et al., 2012) revealed that they have lead contents of about 1.4\%. A Late Bronze Age tin ingot from Sursee-Gammainseli in Switzerland was also found to contain approximately $1.5 \%$ lead (Nielsen, 2014). A tin ring-shaped rod (T1:60) from the Scandinavian Bronze Age context was found to contain $0.77 \%$ lead, $0.12 \%$ antimony and $0.13 \%$ copper by SEM-EDS (Ling et al., 2014). Although XRF data (for Tollense tin), SEM-EDS data (for Scandinavian tin) and the data for Sursee tin (for which the analytical method was not specified) cannot be directly compared with the bulk ICP-MS data, such significant lead contents indicate a very different source of tin from either the Salcombe or the Uluburun tin ingots. 


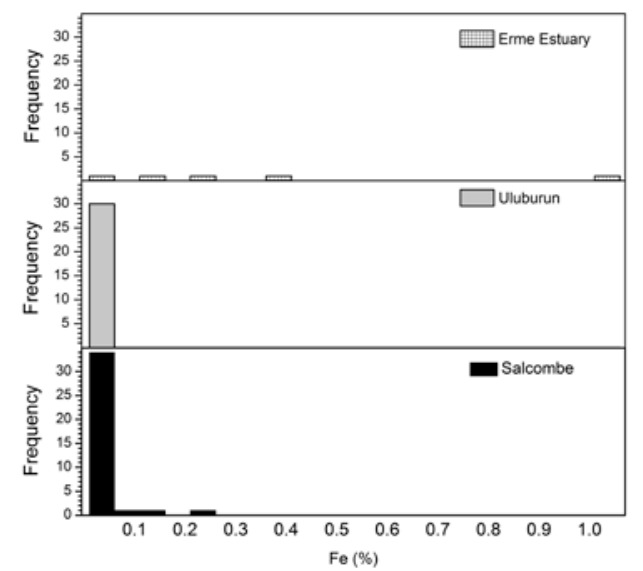

3a

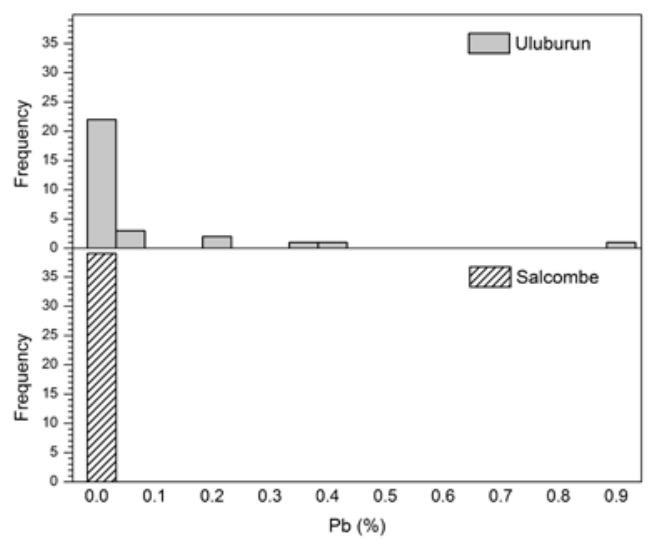

$3 b$

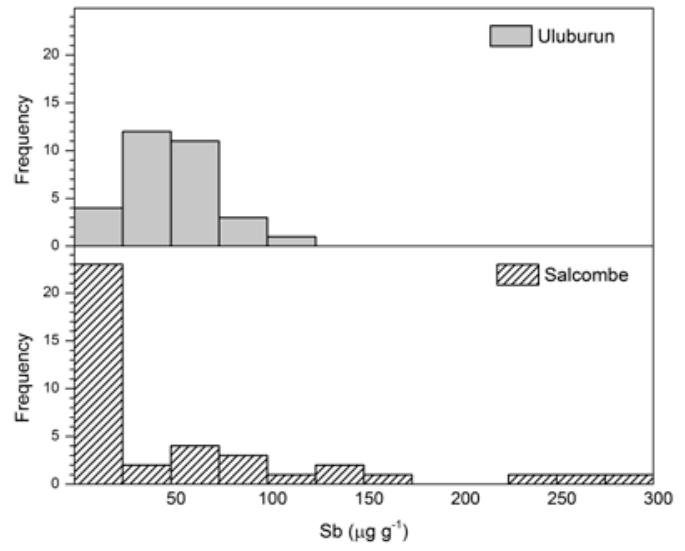

$3 c$

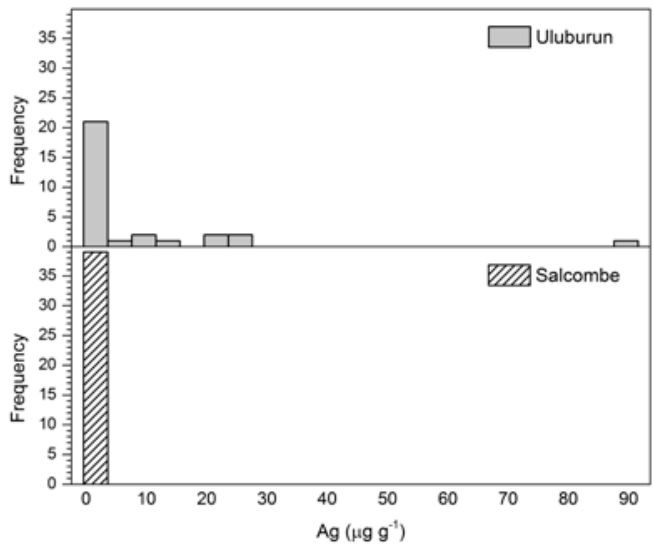

3d

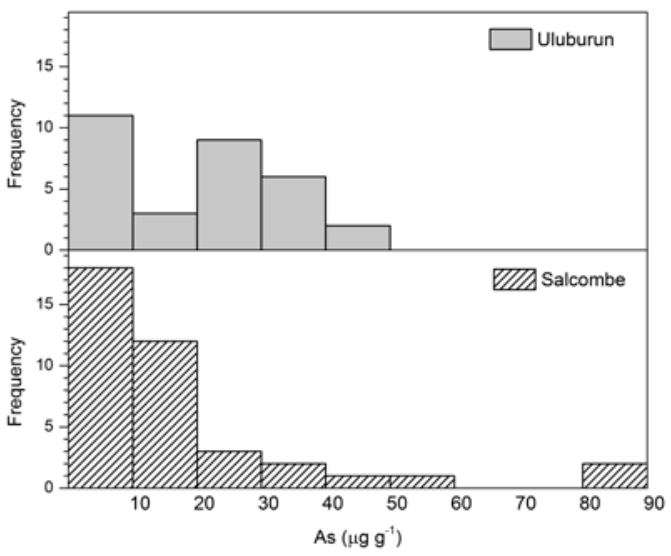

3e

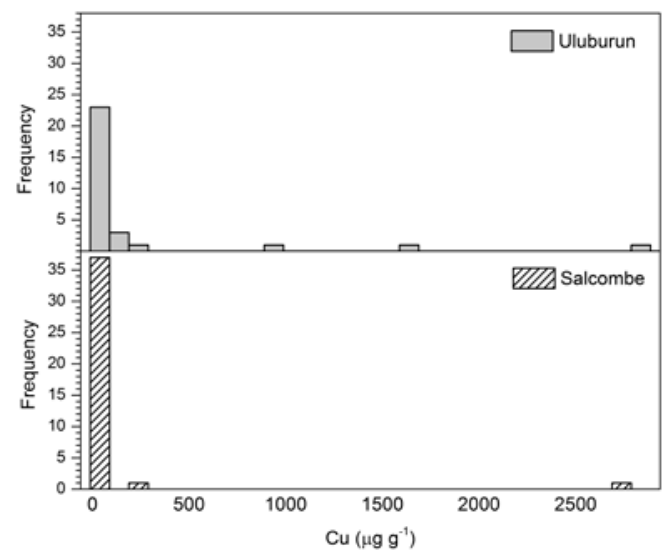

$3 f$

Fig. 3. Histograms of trace element concentrations in tin ingots from Salcombe and Uluburun as well as Erme Estuary (only for iron). 


\subsubsection{Antimony}

Average concentrations of antimony in the Salcombe ingots and the Uluburun ingots are

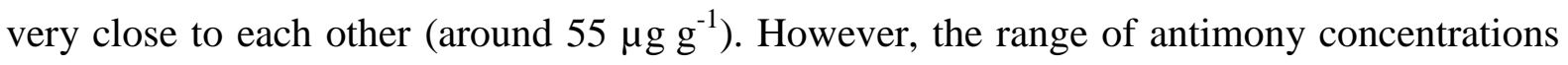
in the Salcombe ingots is broad (4-289 $\mu \mathrm{g} \mathrm{g}^{-1}$ ) and the distribution is skewed so that about $60 \%$ of them contain antimony at concentrations below $25 \mu \mathrm{g} \mathrm{g}^{-1}$ and a median value is $13.3 \mu \mathrm{g} \mathrm{g}^{-1}$; while this is not the case for the Uluburun ingots (as mentioned earlier, one Uluburun ingot (KW3935) containing unusually high amount of antimony is excluded from all calculations) (Fig. 3c). Both analysed Erme Estuary ingots contain antimony at similarly low levels.

\subsubsection{Silver}

All the Salcombe ingots (and the two analysed Erme Estuary ingots) contain only ultratrace amount of silver (less than $1.4 \mathrm{\mu g} \mathrm{g}^{-1}$ and in $80 \%$ of cases below the limit of quantification of $0.1 \mu \mathrm{g} \mathrm{g}^{-1}$ ). This seems to be in contrast to Uluburun ingots, in which the reported concentrations of silver are up to $90 \mu \mathrm{g} \mathrm{g} \mathrm{g}^{-1}$ (Fig. 3d) and even reaching $240 \mu \mathrm{g} \mathrm{g}^{-1}$ in an antimony-rich ingot (KW3935) not considered here.

\subsubsection{Arsenic}

Over $90 \%$ of the Salcombe ingots contain arsenic at concentrations below $50 \mu \mathrm{g} \mathrm{g}^{-1}$ and all the Uluburun ingots and the analysed Erme Estuary ingots do not exceed this level of concentrations (Fig. 3e).

\subsubsection{Copper}

The Salcombe ingots generally contain less copper $(70 \%$ of ingots with less than $10 \mu \mathrm{g} \mathrm{g}^{-1}$; its median concentration is less than $5 \mu \mathrm{g} \mathrm{g}^{-1}$ ) than the Uluburun ingots (median concentration is $40 \mathrm{\mu g} \mathrm{g}^{-1}$; Fig. 3f). However, one ingot (2010.8032.323) is copper-rich $(0.27 \% \mathrm{Cu})$ and is also slightly enriched in gold and lead.

\subsubsection{Indium}

Although indium is known to accumulate in tin deposits, little reliable data exist so far for the concentration of this element in ancient tin. Tin minerals from Cornwall-type deposits may typically contain indium at levels of $200-700 \mu \mathrm{g} \mathrm{g}^{-1}$ in cassiterite $\left(\mathrm{SnO}_{2}\right)$ and $2100 \mu \mathrm{g} \mathrm{g}^{-1}$ in stannite $\left(\mathrm{Cu}_{2} \mathrm{FeSnS}_{4}\right)$ (Briskey, 2005). Our ICP-MS analysis (using ${ }^{113} \mathrm{In}$ ) shows that the concentrations of indium in the Salcombe and Erme Estuary ingots are in the range of 4.5-40.4 $\mathrm{\mu g} \mathrm{g}^{-1}$ with a median concentration of $14.9 \mu \mathrm{g} \mathrm{g}^{-1}$. Previously published ICP-MS data on Bronze Age pure tin objects (Northover and Gillis, 1999) are probably subject to significant overestimation of indium due to an isobaric interference of the ${ }^{115} \mathrm{Sn}$ ( $0.34 \%$ isotopic abundance) on ${ }^{115}$ In measured, which cannot be resolved by quadrupole- 
based instruments. Similarly, the study of Mediterranean tin scraps (Valera and Valera, 2003) does not give any technical details on the ICP-MS method and indium concentrations reported might also be suffering from tin or cadmium (Cd) isobaric interferences.

\subsubsection{Bismuth}

All the Salcombe ingots contain bismuth at concentrations below $130 \mu \mathrm{g} \mathrm{g}^{-1}$, with over $50 \%$ ingots being of less than $10 \mu \mathrm{g} \mathrm{g}^{-1}$ and a median concentration of $6.54 \mu \mathrm{g} \mathrm{g}^{-1}$. Bismuth was not generally determined in the Uluburun ingots so comparison is not possible. One out of the two Erme Estuary ingots analysed here has a much higher bismuth content $\left(1680 \mu \mathrm{g} \mathrm{g}^{-1}\right)$.

Nickel, cobalt (Co) and zinc are mostly below detection limits in both the Salcombe and Uluburun ingots, and below $30 \mathrm{\mu g} \mathrm{g}^{-1}$ in a few cases when detected.

\subsection{Microstructure}

\subsubsection{Surface corrosion layers}

All of the samples examined were covered with corrosion products on the surface and have unaltered metal remaining in the centre (Fig. 4). The surface crust varies in thickness, ranging from a thin layer of less than $200 \mu \mathrm{m}$ to almost the entire thickness of the ingots in some cases with one ingot $(2013,8032.5)$ appearing completely corroded. SEM-EDS analysis of the metallurgical samples identified a layer of the Sn-O-Cl phase, in most cases abhurite $\left[\mathrm{Sn}_{21} \mathrm{Cl}_{16}(\mathrm{OH})_{14} \mathrm{O}_{6}\right]$, normally formed next to unaltered metal followed by a layer of Sn-O phase, in most cases romarchite (SnO), which was confirmed by XRD. A thin layer or agglomerates of a seemingly different phase with potentially lower $\mathrm{Sn} / \mathrm{O}$ ratio was sometimes observed at the boundary between $\mathrm{Sn}-\mathrm{O}-\mathrm{Cl}$ phase and Sn-O phase and may be composed of cassiterite $\left(\mathrm{SnO}_{2}\right)$ (Dunkle et al., 2004). The surface crust does not always have a clear layered structure; it often consists of a mixture of tin oxides as well as islands of metallic tin (Fig. 5). A mixture of $\mathrm{Sn}_{21} \mathrm{Cl}_{16}(\mathrm{OH})_{14} \mathrm{O}_{6}, \mathrm{SnO}$ and $\mathrm{SnO}_{2}$ was indeed identified by XRD in the drillings discarded during sampling for chemical composition analysis. The pattern of corrosion and the chemical composition of phases resemble closely the products formed during the corrosion of pewter artefacts from the Queen's Anne Revenge (AD 1718) (Dunkle et al., 2003) and other marine finds (Dunkle et al., 2004). 


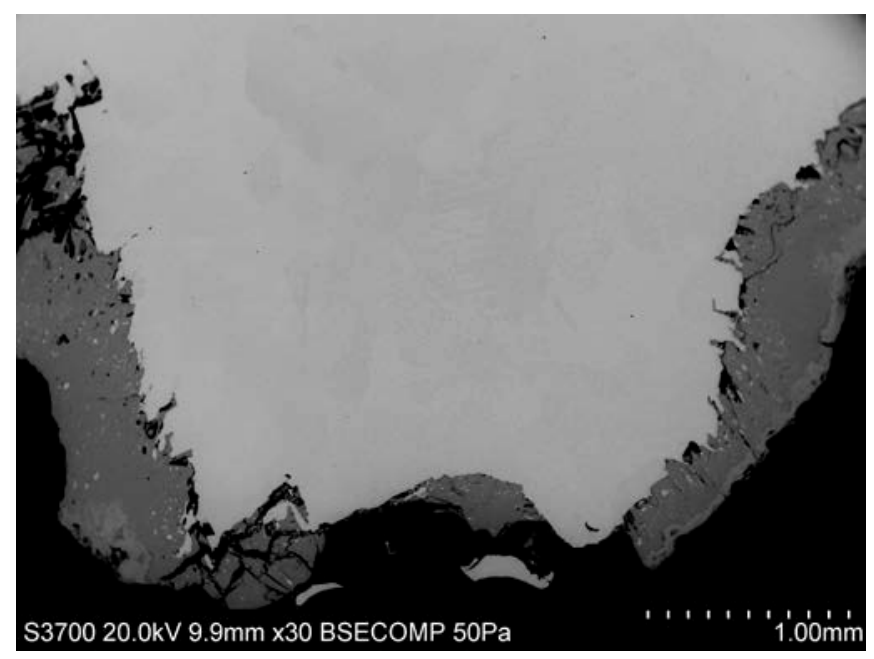

Fig. 4. SEM image of Salcombe tin ingot 2010,8032.311, showing surface oxidation crust and unaltered metal remaining in the centre.

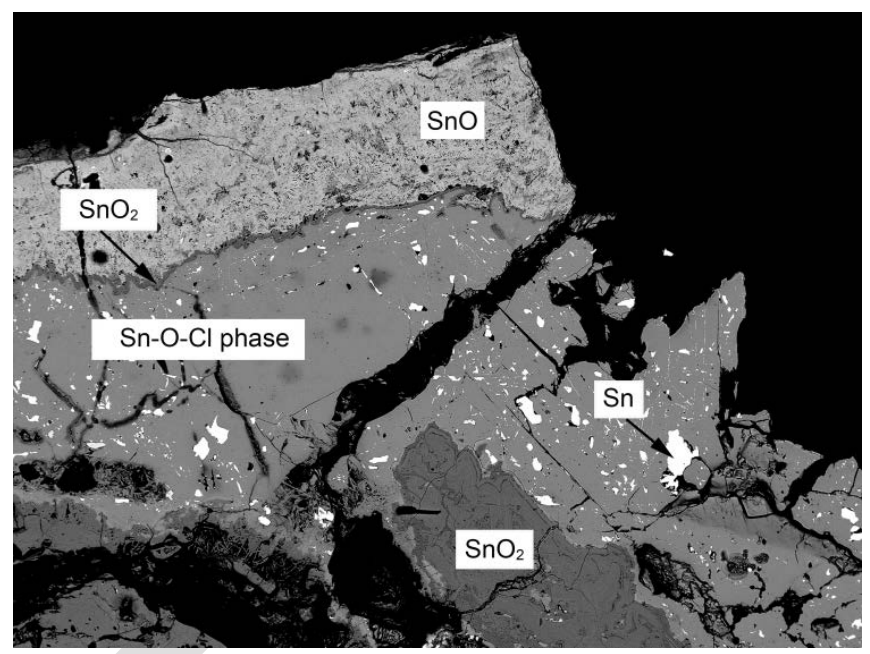

Fig. 5. SEM image of Erme Estuary ingot 2013,8031.1, showing surface crust consisting of a mixture of $\mathrm{SnO}, \mathrm{SnO}_{2}$ Sn-O-Cl phases and residual metallic tin.

\subsubsection{Metallic tin}

The microstructure of the metallic tin of the ingots shows homogeneous compositions with mini pores of generally less than $1 \mu \mathrm{m}$ in diameter (Fig. 6) or even smaller in some of the samples, e.g. no. 2010,8032.308. The tin ingots (as their compositions showed) appeared generally quite pure, however, inclusions are found in the microstructure of all ingots except $2013,8032.297 \& 306$.

\subsubsection{Inclusions in the metal}

Tin-iron intermetallic inclusions are known in archaeological tin (Northover and Gillis, 1999). Most ingots studied here (Salcombe ingots 2010,8032.302, 308, 310, 311, 313 and Erme Estuary ingots 2013,8031.1 \& 2) contained $1 \mu \mathrm{m}-100 \mu \mathrm{m}$ crystal-like grains with approximate composition $\mathrm{FeSn}_{2}$ - 'the commonest and best known' of iron-tin intermetallic compounds (Louis, 1911). The largest number of $\mathrm{FeSn}_{2}$ inclusions (known as hard head) is observed in the Erme Estuary ingot 2013,8031.1 with 0.23\% iron in bulk composition (Fig. 7). The same ingot also contains less abundant grains of an intermetallic with a composition close to SnFe, which was not found in any other ingots (containing less iron in bulk chemical composition according to the ICP-MS analysis). The FeSn $n_{2}$ inclusions seem to be resisting oxidation better than the pure tin matrix (Northover and Gillis, 1999) and were found in the 'romarchite' zone of tin oxidation products in several ingots, while fragments of pure tin remain only in the 'abhurite' layer, which may have formed as the first stage of tin corrosion 
(Dunkle et al., 2004). All tin ores contain appreciable amount of iron, which can be easily removed by re-melting or refining when forming as hard head, so the iron content in metallic tin is a factor of the smelting and more specifically of the refining. A recent study of tin ingots from the Gresham ship suggests that the local enrichment in iron may derive from the material of the mould where the ingots were cast (Birch et al., 2014).

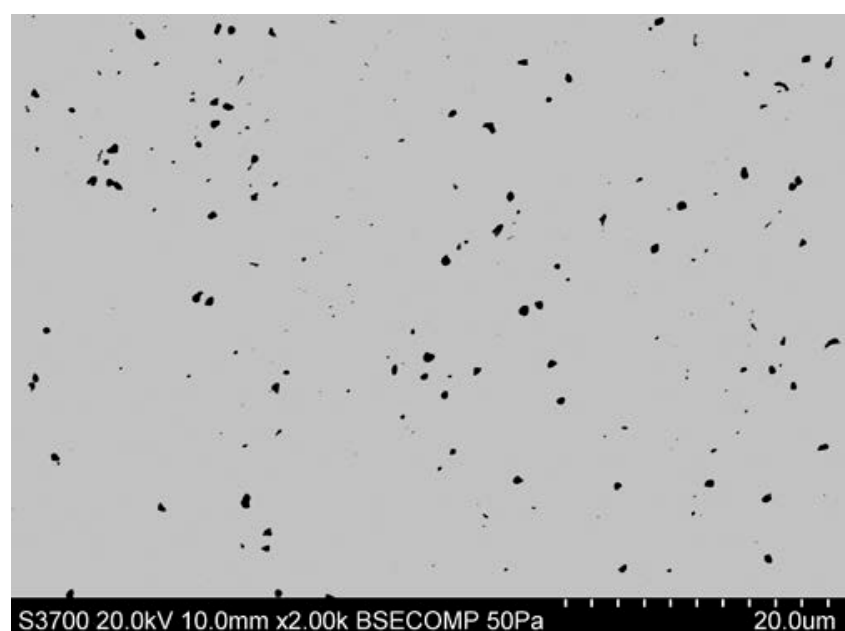

Fig. 6. SEM image of Salcombe ingot 2010,8032.313, showing small pores present in the metal..

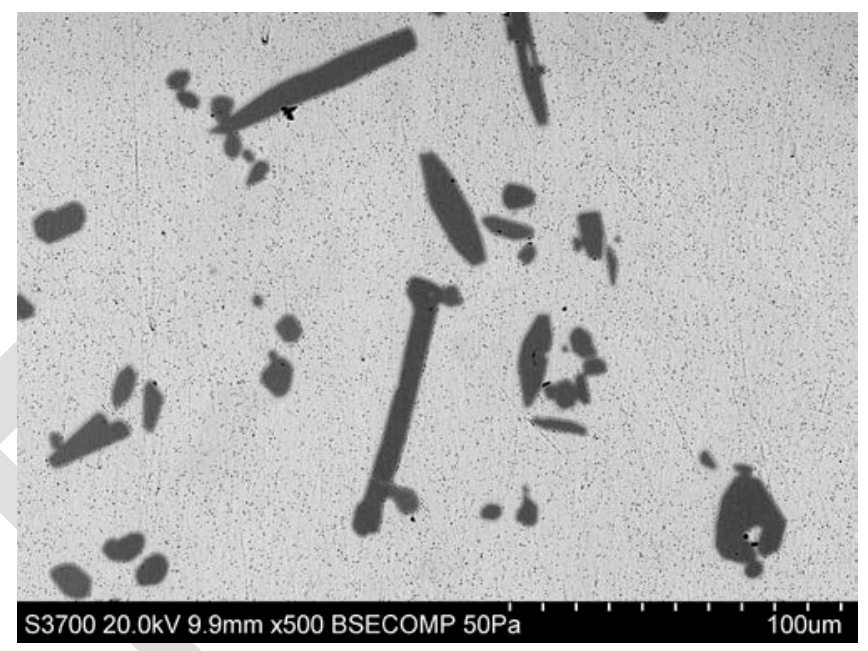

Fig. 7. SEM images of the Erme Estuary tin ingots, showing iron-tin (Fe-Sn) intermetallic compounds (large dark features) present in the metal.

Ingot $2010,8032.323$ is unusual among the Salcombe tin ingots due to its high bulk copper content $(0.27 \%)$. Copper is found to segregate into inclusions that are probably too small for quantitative SEM-EDS analysis, however, copper-tin (Cu-Sn) intermetallic compounds - the phases widely known in tin alloys (Barry and Thwaites, 1983) - are observed (Fig. 8) and some of them were found to also contain iron. This type of inclusions has not been found in any other ingots in this study. 


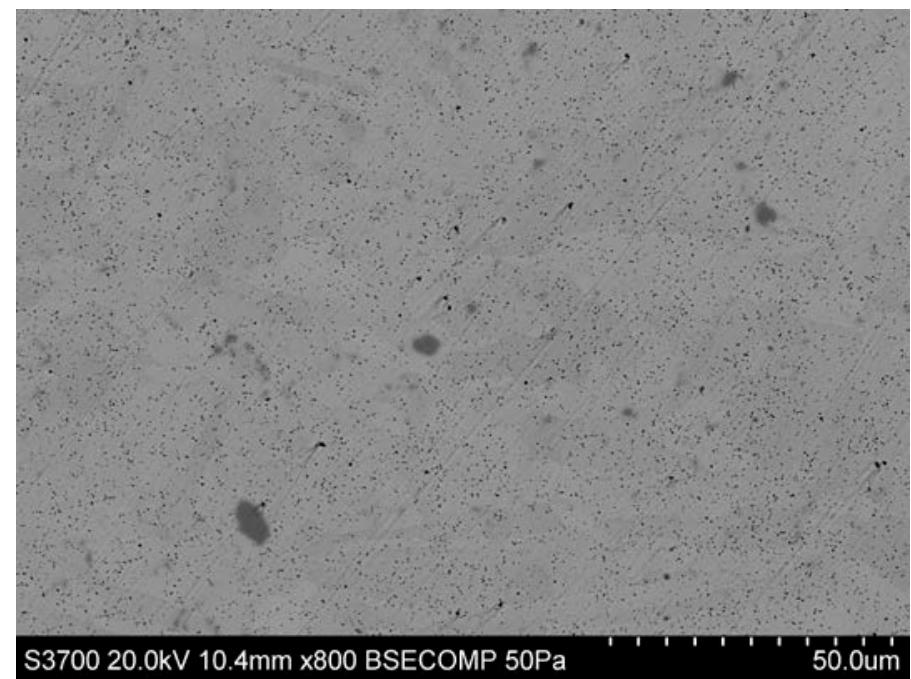

Fig. 8. SEM image of Salcombe ingot 2010,8032.323, etched, showing copper-tin (Cu-Sn) intermetallic compounds (large dark spots) present in the metal. Uneven brightness of the tin matrix is the result of etching

Very small grains of hexagonal shape with the composition of approximately $\mathrm{SnCu}_{0.1} \mathrm{~S}$ were observed in the Erme Estuary ingots 2013,8031.1 \& 2 and the Salcombe ingots 2010,8032.310, $311 \& 313$.

Several small (c. $2.5 \mu \mathrm{m}$ ) bismuth-rich inclusions are found in the oxidation crust of Erme Estuary ingot 2013,8031.1 characterised by unusually high bulk bismuth content $(0.17 \%)$. Due to the small size of the inclusions it was not possible to tell whether they are composed of pure bismuth or of a Bi-Sn intermetallic. Although such inclusions were not found in the unaltered metal, it is likely that they are original features of this ingot. They may have predominantly populated one side of the ingot due to a large difference in density between bismuth and tin and remained unaltered during tin oxidation due to their higher resistance to corrosion (Northover and Gillis, 1999).

Arsenic-rich inclusions were not identified in the Salcombe ingot 2010,8032.308 which contains more arsenic (86 $\mathrm{\mu g} \mathrm{g}^{-1}$ ) than any other ingots, although a couple of very small arsenic-rich grains were found in the samples of 2010,8032.311 and 2010,8032.323.

\section{Discussion}

\subsection{Tin production}

The evidence for Bronze Age tin mining and smelting in southwest England that could have produced the Salcombe tin ingots remains extremely limited. There are no confirmed Bronze Age tin mining sites in southwest England with later mining activities up until the $20^{\text {th }}$ century leaving only circumstantial evidence (Craddock and Craddock, 1996). The recent 
comprehensive environmental analyses of tin, lead and copper levels within undisturbed peat bogs on Dartmoor and Bodmin moor indicated only potential tin extraction from around AD 100 and not earlier (Meharg et al., 2012). However, locally available cassiterite has been found at Bronze Age sites such as the settlement site of Trevisker, Cornwall dating to c. 1700 to $1300 \mathrm{BC}$ which revealed three groups of cassiterite pebbles: 20 in Structure B, two in House A and one in House C (ApSimon and Greenfield, 1972) although whilst geological identification was performed, no compositional analyses were published (Penhallurick, 1986). The discovery of Bronze Age bronze metalwork in alluvial tin streams (see Pearce, 1983; Penhallurik, 1986 with the bias towards Cornwall rather than Dartmoor/Bodmin moor at least partially due to the intensity of $18^{\text {th }}-19^{\text {th }}$ century re-workings) strongly implies that alluvial sources were exploited (cf. Shell, 1979). Haustein et al. (2010) carried out tin isotope analysis on 50 tin ores from the Erzgebirge region and 30 tin ores from Cornwall and argued that the tin source for the Nebra sky disc, typologically dated to c. 1600 BC, was probably Cornish. It is hoped that tin isotope analysis to be carried on these Salcombe and Erme Estuary/Bigbury Bay tin ingots in the future to answer the question of provenance.

With regards to the Salcombe and Erme Estuary tin ingots, the Erme river is draining areas very rich in tin (1385-2000 $\mathrm{g} \mathrm{g} \mathrm{g}^{-1}$ in stream sediments; BGS, 2000) so it is not surprising that $16^{\text {th }}$ century alluvial tin streamworks are known within its valley (Gerrard, 1996). The stratigraphical and geochemical analysis of a palaeochannel in the Erme river indicate that tin extraction in the Salcombe vicinity was potentially occurring from at least $4^{\text {th }}$ $-7^{\text {th }}$ century AD (Thorndycraft et al., 2004). The modern Salcombe-Kingsbridge Estuary is unusual because no large river feeds it. Tin levels in sediments within the Salcombe catchment are not as high as in the Erme catchment, but are still elevated in some part of it (above $42 \mu \mathrm{g} \mathrm{g}^{-1}$; BGS, 2000). If the sources of tin ingots from the Salcombe and Erme estuaries are local it is likely to be placers in the South Dartmoor area that would be sampling a number of deposits exposed by periglacial conditions after last Ice Age (Chris Stanley, pers. comm.).

There is more direct evidence for Bronze Age tin smelting in southwest England. Fox (1957) reported potential signs of tin metallurgical activity during excavations at the settlement site of Dean Moor (upper part of the river Avon, only about $4 \mathrm{~km}$ from the river Erme) probably dating to the Late Bronze Age: a pebble of cassiterite and a small bead of unusual reddish tin slag - not tin metal as reported elsewhere (Pearce, 1983; Penhallurick, 1986) - $3.2 \mathrm{~mm}$ in diameter was found in one of the excavated settlements (Hut 5B) (Malham, 2010). Two cassiterite pebbles and six tin slag fragments - the latter representing a secondary 
deposition with a bronze dagger - as well as a seventh from the soil above were also found at a ring-banked enclosure dating to c. 1500 BC at Caerloggas Down, Cornwall (Miles, 1975; Tylecote, 1975; Biek, 1979; Salter, 1997; Malham, 2010). Across the English Channel, the analysis of tin smelting slag at the site of St Renan, Finistère dating to 1387-1084 cal BC (Giot et al., 1998; Mahé-le Carlier et al., 2001) provides the only evidence for tin smelting in northwest France. Very few tin slags have ever been found throughout Bronze Age Europe due to the smelting of the tin oxide cassiterite $\left(\mathrm{SnO}_{2}\right)$, the way metallic tin was produced during the Bronze Age, produced virtually no slag, since alluvial cassiterite is about $80 \%$ pure tin (Muhly, 1993). However, the mining of low grade tin ores containing higher levels of haematite, followed by through beneficiation by hand, could also have occurred with similar consequences for archaeological visibility (Yener and Vandiver, 1993).

There is certainly growing evidence for Bronze Age copper and gold exploitation in southwest England. The dating of copper mining to 1950-1750 BC at Roman Lode, Exmoor (Juleff and Bray, 2007) supports the compositional analyses of copper-alloy objects by Bray and Pollard (2012) which demonstrate the contemporary extraction of copper from southwest England. The exploitation of gold sources in southwest England has been argued on the basis of recent lead isotope analyses of 50 Chalcolithic - Early Bronze Age (c. 2500-1500 BC) gold objects in Ireland demonstrating non-local sources (Standish et al., 2015). This does not mean that gold sources in Ireland were not exploited during this period - as has been argued for the Mourne Mountains, Ireland - and the prospecting for gold may also have been accompanied extraction of tin (Warner et al., 2010a, 2010b). There is also now widespread evidence for secondary bronze production activities, usually in the form of mould fragments, in Middle-Late Bronze Age (c. 1500-800 BC) settlement sites in southwest England (Knight, 2014; Jones et al., 2015) which reflects broader patterns of mould deposition across southern England (Brown and Medlycott, 2013).

\subsection{Tin objects}

The evidence for Bronze Age tin objects in southwest England beyond the Salcombe tin ingots is only slightly more extensive than the evidence for tin production. The recent discovery of an exceptionally well preserved cist burial in the peat on Whitehorse Hill, Dartmoor, Devon dating to c. 1900-1700 BC revealed a young adult with a bracelet of 35 small tin studs as well as a cylindrical tin bead on a composite necklace of amber, Kimmeridge shale and clay beads (Jones et al., 2014). The closest surviving contemporary parallels for tin ornamentation are found in continental Europe as with the 47 segmented tin 
beads found in a female grave at Buxheim, Bavaria dating to 2210-1960 BC (Möslein and Rieder, 1998) and the necklace of 25 tin beads (7 segmented, 18 plano-convex), 13-14 amber beads, one bronze bead and four segmented faience beads found at Exloo, Netherlands and dated typologically to the earlier $2^{\text {nd }}$ millennium BC (Haveman et al., 2006). The only other tin bead from Britain in a comparable context was found in an Early Bronze Age barrow at Sutton Veny G11c, Wiltshire during antiquarian excavations and subsequently lost (Penhallurick, 1986). Tin objects remain exceptionally rare, even within the wide diversity of materials found in Early Bronze Age (c. 2200-1500 BC) funerary contexts in Britain (Woodward and Hunter, 2015). The use of tin as an inlay within other materials in Bronze Age (c. 2200-800 BC) Britain as with the jet button found in the cist burial at Rameldry, Fife, Scotland dating to c. 2200-1900 BC (Baker et al., 2003) or the Middle-Late Bronze Age (c. 1500-800 BC) Caergwrle bowl found in northeast Wales (Davis and Townsend, 2009) is similarly very infrequent. The discovery of potentially Bronze Age tin ingots in southwest England, some comparable to the rough form found at Salcombe, at sites such as Penwithick, St Wenn/Landjew Farm, Tremethack Moor, Burngullow, Vellin Antron Farm and Mabe have unfortunately occurred in unstratified or poorly recorded contexts (Penhallurik, 1986; Malham, 2010).

The discovery of the 44 tin ingots at Bigbury Bay at the mouth of the river Erme (Fox, 1995, 1996) - of which two ingots feature in the analyses in this paper - are also unstratified finds with no datable or typologically diagnostic associations. It is certainly possible that the ingots could date to the Bronze Age (cf. SWAG 1993), rather than the Iron Age (cf. Fox 1995; 1996), as the form of the ingots is inconclusive.

\subsection{Compositions of tin from different sites}

It is difficult to make a meaningful comparison of the Salcombe with Bigbury Bay/Erme Estuary ingots because of the much smaller sample size in the latter. The two Erme Estuary ingots analysed in this study do not necessarily belong to the same workshop / ore source based on both the significantly different bulk contents of iron and bismuth and inclusions in their microstructures. One ingot is significantly enriched in iron and the other in bismuth and slightly in cobalt and nickel. Even though the bulk concentration of iron can reflect the degree of tin refining it may depend on the representativeness of a sample obtained by drilling as intermetallic Fe-Sn compounds may tend to concentrate in one part of the ingot (as observed in 2013,8031.1) - potentially due to their higher density (Kwon et al., 2003) - and the results may be biased depending on what side of the ingot was drilled. If both Salcombe 
and Bigbury Bay/Erme Estuary tin ingots derive from ores in the same region which is assumed to be southwest England, the difference in trace element patterns suggest that they may have been produced by different smelting and refining methods. With the chemical composition alone it is not possible to identify if the Salcombe and Bigbury Bay/Erme Estuary ingots have been from the same source.

The comparison of the Salcombe tin ingot trace element compositions to other analysed Bronze Age tin objects reveals some variation which can provide insights into provenance. All of the published data encompassing the few sites where Bronze Age tin objects have been found and their trace elements analysed, shows that tin found from different regions has different impurity patterns which will help to lead us to the sources of the tin in the future with more archaeological and scientific data becoming available - with the caveat that the same ore sources may have variable trace element compositions. Currently, the main difference in trace elements between the Uluburun and Salcombe tin ingots, the only two sites where large numbers of analyses have been carried out, is the contents of lead and silver. This suggests, unsurprisingly given the geographical distance between the two sites, that these two groups of ingots were smelted from ores of quite different composition. The ICP-MS analysis of five Late Bronze Age tin fragments found in the Nuragic sanctuary of S’Arcu 'e is Forros, Sardinia reported by Valera and Valera (2003) shows a significantly

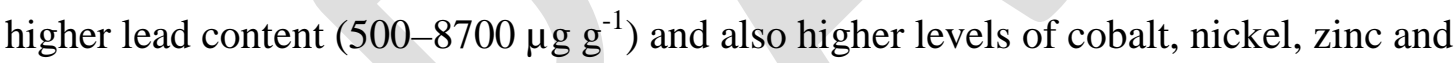
copper than the Salcombe ingots. The use of lead isotope analysis as well as trace element analysis in analysing the provenance of tin has suggested that the Uluburun tin ingots contain at least two groups, and tin ingots from Hishuley Carmel off the Israeli coast may have been from the same source as one of the Uluburun groups (Stos-Gale et al., 1998) and also that the Sardinian tin objects were not produced locally (Valera and Valera, 2003). The future use of lead and tin isotope analyses could well provide further insights into the provenance of the Salcombe ingots (cf. Haustein et al., 2010; Standish et al., 2014, 2015).

\subsection{Importance of the Slacombe tin ingots}

The morphology of the Salcombe and Erme Estuary/Bigbury Bay ingots strongly implies that they were roughly cast in a hollow in the ground or perhaps into the sand, thus limiting any typological distinctions (cf. Timberlake, 1994; Gomez-Ramos, 1993a). There is a very wide and uneven distribution of weights in the tin ingots, although most of them are original in size and complete and not broken/fragmented (Table 1). Two copper alloy rectanguloid blocks have been found at Salcombe - one smooth weighing 44.7 g (Needham et al., 2013) 
and one with wavy mouldings weighing 29.8 g (2010,8032.35) - have strong parallels in weights found in Middle-Late Bronze Age contexts in western central Europe (Pare, 1999, 2013). Whilst the issue of weight measurement will not be analysed in depth in this paper, there is no straightforward proportional correlation between the weights of these rectanguloid blocks and the tin ingots, nor is there any obvious regularity within the weights of the tin ingots themselves. The weights of the tin ingots also do not correlate to Bronze Age weight units identified in continental Europe - such as the $48.8 \mathrm{~g}$ and $104 \mathrm{~g}$ for the Late Bronze Age in France and Switzerland (Pare, 2013) or $61.3 \mathrm{~g}$ for central Europe during the $13^{\text {th }}$ century BC (Pare, 1999). However, there can be little doubt that weights were being measured across Bronze Age Temperate and Mediterranean Europe and that these frequently related to metals (Pare, 1999; Pulak, 2000b; Lo Schiavo, 2006; Rahmstorf, 2010; Roscio et al., 2011).

The only potentially comparable Bronze Age shipwreck site to Salcombe in northwest Europe is at Langdon Bay, Dover, Kent, southeast England which comprises 360 bronze objects typologically dating to the Middle Bronze Age Penard metalwork phase (c. 13001150 BC) (Needham et al., 2013). However, there were no tin objects found at Langdon Bay nor any typologically diagnostic Bronze Age tin objects found off the coasts of Britain and the near Continent (Needham et al., 2013). Whilst tin ingots were recovered from the Bronze Age shipwreck sites at Uluburun (Pulak, 2000a; Hauptmann et al., 2002) and Cape Gelidonya (Bass, 1967, 2010; Stos-Gale et al., 1998), these site provide insights into the interconnections spanning the Bronze Age palaces, towns, cities and states in the eastern Mediterranean, but are of limited relevance for understanding of the smaller-scale Bronze Age farming societies in Central, Western and Northern Europe. The shipwreck at Rochelonge, Agde, southeast France, which comprised 32 tin ingots amongst the c. 1700 objects recovered and dates to c. $600 \mathrm{BC}$, is more closely comparable despite being at least two centuries later and connected to the rapidly changing Mediterranean world (Hugues, 1965; Bouscaras, 1971). However, this Iron Age assemblage remains very poorly published and the tin ingots have yet to be analysed archaeometallurgically. The maritime movement of copper, tin, bronze and gold throughout Bronze Age Europe remains only directly evidenced at a few shipwreck sites (Gomez-Ramos, 1993b) and the presence of tin ingots at Salcombe makes it unique to northwest Europe.

The production and maritime movement of pure tin ingots as evidenced at Salcombe is important not only for being very rare direct evidence for the Bronze Age tin trade, it also implies the desire to control tin compositions in bronze objects. The implication of the 360 Bronze Age bronze objects at Langdon Bay (Needham et al., 2013) is of an exchange in 
finished bronze metalwork which can be recycled, but with no real control over the resulting alloy's composition. This exchange and recycling of bronze in northwest Europe is only partially revealed in the complexities of cross-channel inter-connections demonstrated in the typologies of deposited Middle-Late Bronze Age bronze metalwork (Brandherm and Moskal del Hoyo, 2014; Matthews, forthcoming; Needham, forthcoming). In contrast, the desired ability to add tin is demonstrated by higher tin contents in specific object types such as c.1014\% tin found in bronze shields (Uckelmann, 2012; Wang et al., forthcoming) and in cauldrons (Northover, 2010; Wang, 2016) from c. 1300 BC.

There is no surviving evidence for any Bronze Age boat at Salcombe site. It can only be assumed that either contemporary sewn plank vessels such as found at Ferriby, northeast England (Wright et al., 2001; Van der Noort et al., 2014) or Dover, southeast England (Clark, 2004), or log boats as found at Carpow, southeast Scotland (Strachan, 2010) were involved in transporting the objects recovered. The locations of the departure and destination are unknown with the debate complicated by the high probability that two temporally distinct Bronze Age shipwrecks can be identified at Salcombe. It cannot be simply assumed that the tin production site for the ingots was nearby despite the geological potential within the vicinity of the Erme Estuary (cf. Kassianidou, 2003 on the interpretation of the production sites for the Uluburun and Haifa ingots). The Scandinavian Bronze Age tin ring-shaped rod (T1:60) was found to be fully consistent with the lead isotope compositions of ores from Cornwall (Ling et al., 2014).The evidence for the intensity and sophistication of maritime movement throughout northwest Europe (Gomez-Ramos 1993b; Van der Noort, 2006; Robinson, 2013) cautions against any simplistic assumptions.

\section{Conclusions}

All the Salcombe tin ingots analysed appeared to be quite pure with little variation in composition between them with only two samples being found to contain over $0.1 \%$ iron and one contain over $0.1 \%$ copper. The compositions of the Salcombe tin ingots do not seem to connect them to any analysed tin samples found elsewhere, e.g. Uluburun, Sardinia. Connection between the Salcombe and Erme Estuary ingots is not clear and requires further investigations. Although it is difficult to compare the compositions of tin ingots from the Erme Estuary and Salcombe because of a small number of analyses for the former, the Erme Estuary ingots do seem to contain higher levels of iron than the Salcombe ingots, indicating different smelting and refining methods used for the tin ingots from these two sites despite them being found in the same region. Further studies of these two sites including 
identification of the date of the Erme Estuary finds, lead and tin isotope analysis of the ingots, compositional and isotopic analyses of known tin samples and ores from different regions, particularly Cornwall and Devon, are needed to answer the question of provenance of the tin ingots, so as to contribute to the study of metal trading.

\section{Acknowledgements}

We are grateful to two anonymous reviewers for their comments that greatly improved the quality of the manuscript. We would like to thank Mike Palmer and Jim Tyson of the South West Maritime Archaeology Group for providing information on the Erme Estuary ingots, Craig Williams of the British Museum for Fig. 1, and Paul Craddock and Duncan Hook of the British Museum and Chris Stanley of the Natural History Museum, London for their constructive comments on the paper.

\section{References}

ApSimon, A.M., Greenfield, E., 1972. The excavation of the Bronze Age and Iron Age settlement at Trevisker Round, St Eval, Cornwall. Proc. Prehist. Soc. 38, 302-381.

Bachmann, H.-G., Jockenhövel, A., Spichal, U., Wolf, G., 2004. Zur bronzezeitlichen Metallversorgung im mittleren Westdeutschland: Von der Lagerstätte zum Endprodukt. Berichte der Kommission für Archäologische Landesforschung in Hessen 7 (2002/2003), $67-120$.

Baer, K. E.v., 1876. Von wo das Zinn zu den ganz alten Bronzen gekommen sein mag?

Archiv für Anthropologie 9, 263-267.

Baker, L., Sheridan, A., Cowie, T., 2003. An Early Bronze Age 'dagger grave' from Rameldry Farm, near Kingskettle, Fife. Proc. Soc. Antiq. Scot. 133, 85-123.

Barry, B.T.K, Thwaites, C.J., 1983. Tin and its Alloys and Compounds. Ellis Horwood, Chichester.

Bass, G.F., 1967. Cape Gelidonya: A Bronze Age Shipwreck. Transactions of the American Philosophical Society 57/8, Philadelphia.

Bass, G.F., 2010. Cape Gelidonya shipwreck, in: Cline, E.H. (Ed.) The Oxford Handbook of The Bronze Age Aegean. Oxford University Press, Oxford, pp. 797-803.

Begemann, F., Kallas, K., Schmitt-Strecker, S., Pernicka, E., 1999. Tracing ancient tin via isotope analyses, in: Hauptmann, A., Pernicka, E., Rehren, T., Yalçin, Ü. (Eds.), The Beginnings of Metallurgy. Der Anschnitt 9. Deutsches Bergbau-Museum, Bochum, pp. 277-284. 
BGS (British Geological Survey), 2000. Regional Geochemistry of Wales and West-Central England: Stream Sediment and Soil. BGS, Keyworth, Nottingham.

Biek, L., 1979. The archaeological tin and iron cycles, in: Scollar, I. (Ed.) Proceedings of the $18^{\text {th }}$ International Symposium on Archaeometry and Archaeological Prospection, Bonn, 14-17 March 1978 (Archaeo-Physika 10), Rheinland-Verlag, Cologne, pp. 75-81.

Birch, T., Charlton, M.F., Biggs, L., Stos-Gale, Z.A., Martinon-Torres, M., 2014. The Cargo, in: Milne, G., Sully, D. (Eds.), The Gresham Ship Project; A 16th-Century Merchantman Wrecked in the Princes Channel, Thames Estuary. Volume II: Contents and Context. Archaeopress, Oxford, pp. 53-69.

Bouscaras, A., 1971. L'épave des bronzes de Rochelongues. Archéologia 39, 68-73.

Brandherm, D., Moskal-del Hoyo, M., 2014. Both sides now: the Carp’s Tongue complex revisited. Antiquaries J. 94, 1-47.

Bray, P.J., Pollard, A.M., 2012. A new interpretative approach to the chemistry of copperalloy objects: source, recycling and technology. Antiquity 86, 853-867.

Briskey, J.A., 2005. Indium in Zinc-Lead and Other Mineral Deposits-A Reconnaissance Survey of 1118 Indium Analyses Published Before 1985. USGS Open-File Report 2005-1209. http://pubs.usgs.gov/of/2005/1209/

Brown, N., Medlycott, M., 2013. The Neolithic and Bronze Age Enclosures at Springfield Lyons, Essex: Excavations 1981-91. East Anglian Archaeology 149, Chelmsford.

Cahill, M., 2009. Tinkering with torcs: an unusual Bronze Age hoard from Kilsallagh, Co. Longford, in: Finlay, N., McCartan, S., Milner, N., and Wickham-Jones, C. (Eds.), From Bann Flakes to Bushmills: Papers in Honour of Professor Peter Woodman. Prehistoric Society Research Paper 1, Oxbow Books, Oxford, pp. 3-11.

Clark, P., 2004. The Dover Bronze Age Boat in Context: Society and Water Transport in Prehistoric Europe. Oxbow Books, Oxford.

Craddock, P.T., Craddock, B.R., 1996. The beginning of metallurgy in south-west Britain: hypotheses and evidence. Mining History: Bull. Peak Dist. Mines Hist. Soc. 13 (2), 5263.

Craddock, P.T., Hook, D.R., 1993. Report on the analysis of three pieces of tin recovered from the Erme Estuary, Devon, Research Laboratory Project Envelope No. 6370, British Museum, London (unpublished).

Davis, M., Townsend, A., 2009. Modelling the Caergwrle bowl: ancient, historic and modern methods, in: Ambers, J., Higgitt, C, Harrison, L., Saunders, D. (Eds.), Holding It All 
Together; Ancient and Modern Approaches to Joining, Repair and Consolidation. Archetype, London, pp. 177-183.

Dayton, J.E., 1971. The problem of tin in the Ancient World. World Archaeol. 3 (1), 49-70.

Dunkle, S.E., Craig, J.R., Rimstidt, J.D., Lusardi, W.R., 2003. Romarchite, hydroromarchite and abhurite formed during the corrosion of pewter artifacts from the Queen Anne's Revenge (1718). Can. Miner. 41, 659-669.

Dunkle, S.E., Craig, J.R., Lusardi, W.R., 2004. Romarchite and associated phases as common corrosion products on pewter artifacts from marine archaeological sites. Geoarchaeology 19, 531-552.

Fox, A., 1957. Excavations on Dean Moor, in the Avon valley, 1954-1956. The Late Bronze Age settlement. Trans. Devon. Assoc. Adv. Sci. Lit. Art 89, 18-77.

Fox, A., 1995. Tin ingots from Bigbury Bay, South Devon. Devon Archaeology Society Proceedings No.53, 11-23.

Fox, A., 1996. Tin ingots from Bigbury Bay, South Devon. Mining History: Bull. Peak Dist. Mines Hist. Soc. 13 (2), 150-151.

Franklin, A.D., Olin, J.S., Wertime, T.A., (Eds.) 1978. The Search for Ancient Tin. Smithsonian Institution, Washington.

Gerrard, S., 1996. The early south-western tin industry: An archaeological view. Mining History: Bull. Peak Dist. Mines Hist. Soc. 13 (2), 67-83.

Giot, P-R., Lulzac, Y. 1998. Datation à l'Âge du Bronze d'une exploitation de cassitérite dans le Finistère. Bull. Soc. Préhist. Fr. 95 (4), 598-600.

Giumlia-Mair, A., Lo Schiavo, F. (Eds.), 2003. The Problem of Early Tin. Acts of the XIVth UISPP Congress, University of Liège, Belgium, 2-8 September 2001. BAR International Series 1199. Archaeopress, Oxford.

Gomez-Ramos, P., 1993a, Tipologia de lingotes de metal y su hallazgo en los depositos del Bronce final de la peninsula ibérica. Cuadernos de Préhistoria y de Archéologia de la Universidad Autonoma de Madrid 20, 73-105.

Gomez-Ramos, P., 1993b. Transporte Marítimo del metal como material prima durante del Bronce Final. Cuadernos de Préhistoria y de Archéologia de la Universidad Autonoma de Madrid 20, 107-131.

Harding, A.F., 2013. World systems, cores, and peripheries in prehistoric Europe. Eur. J. Archaeol. 16(3), 378-400. 
Hauptmann, A., Maddin, R., Prange, M., 2002. On the structure and composition of copper and tin ingots excavated from the shipwreck of Uluburun, Bull. Am. Sch. Orient. Res. 328, 1-30.

Haustein, M., Gillis, C., Pernicka, E., 2010. Tin isotopy - a new method for solving old questions. Archaeometry 52 (5), 816-832.

Haveman, E., Sheridan, J.A., 2006. The Exloo necklace: new light on an old find. Palaeohistoria 47/48, 100-139.

Hugues, C., 1965. La découverte sous-marine de Rochelongue, Agde (Hérault). Comptes rendus des séances de l’ Académie des Inscriptions et Belles-Lettres 109 (1), 176-178.

Huska, A., Powell, W., Mitrović, S., Bankoff, H., Bulatović, A., Filipović, V., Boger, R., 2014. Placer tin ores from Mt. Cer, West Serbia, and their potential exploitation during the Bronze Age. Geoarchaeology 29 (6), 477-493.

Jones, A.M., Marchand, J., Sheridan, A., Straker, V., 2014. Redeemed from the peat: An extraordinary Bronze Age grave on Whitehorse Hill. Brit. Archaeol. 139, 16-21 \& $23 .$.

Jones, A.M., Gossip, J., Quinnell, H. (Eds.), 2015. Settlement and Metalworking in the Middle Bronze Age: New evidence from Tremough, Cornwall. Sidestone Press, Leiden.

Juleff, G., Bray, L., 2007. Minerals, metal, colours and landscape: Exmoor's Roman Lode in the Early Bronze Age. Cambridge Archaeol. J. 17 (3), 285-296.

Kashkay, M.A., Selimkhanov, I.R., 1973. From the history of Ancient Metallurgy of the Caucasus. Elm, Baku (in Russian).

Kassianidou, V., 2003. The trade of tin and island of copper, in: Giumlia-Mair, A, Lo Schiavo, F. (Eds.), The Problem of Early Tin. Acts of the XIVth UISPP Congress, University of Liège, Belgium, 2-8 September 2001. BAR International Series 1199. Archaeopress, Oxford, pp. 109-119.

Knight, M., 2014. Masters of mysteries or haphazard handymen? An assessment of the evidence for metalworkers at Bronze Age settlements in Cornwall and Devon, southwestern England. Trowel 15, 29-41.

Knight, M. Ormrod, T., Pearce, S., 2015. The Bronze Age Metalwork of South Western Britain. A corpus of material found between 1983 and 2014. BAR British Series 610. Archaeopress, Oxford.

Kristiansen, K., Larsson, T.B., 2005. The Rise of Bronze Age Society: Travels, Transmissions and Transformations. Cambridge University Press, Cambridge. 
Krüger, J., Nagel, F., Nagel, S., Jantzen D., Lampe, R., Dräger, J., Lidke, G., Mecking, O., Schüler, T., Terberger, T., 2012. Bronze Age tin rings from the Tollense valley in northeastern Germany. Praehistorische Zeitschrift 87 (1), 29-43.

Kwon, Y.-S., Gerasimov, K.B., Avramchuk, S.S., 2003. Decomposition of FeSn intermetallic induced by mechanical milling. J. Alloy. Compd. 359, 79-83.

Ling, J., Stos-Gale, Z., Grandin, L., Billström, K., Hjärthner-Holdar, E., Persson, P.O., 2014. Moving metals II: provenancing Scandinavian Bronze Age artefacts by lead isotope and elemental analyses. J. Archaeol. Sci. 41, 106-132.

Lo Schiavo, F., 2006. Western weights in context, in Alberti, M.E., Ascalone, E., Peyronel, L. (Eds.), Weights in Context. Bronze Age Weighing Systems of Eastern Mediterranean: Chronology, Typology and Archaeological Contexts. Proceedings of the International Colloquium, Rome (22-24 November 2004), Studi e Materiali 13. Istituto italiano di numismatica, Roma, pp. 359-79.

Lo Schiavo, F., Muhly, J.D., Maddin, R., Giumlia Mair, A. (Eds.), 2009. Oxhide Ingots in the Central Mediterranean. Biblioteca de Antichità Cipriote 8. Leventis Foundation, CNRIstituto di studi sulle civiltà dell’Egeo e del Vicino Oriente, Roma.

Louis, H., 1911. The Metallurgy of Tin. McGraw-Hill Book Co, New York, London.

Mahé-le Carlier, C., Lulzac Y., Giot, P-R., 2001. Etude des déchets de réduction provenant de deux sites d'exploitation d'étain armoricain de l'Age du Bronze et du Moyen Age. Revue archéologique de l'Ouest 18, 45-56.

Malham, A., 2010. The classification and interpretation of tin smelting remains from South West England. A study of the microstructure and chemical composition of tin smelting slags from Devon and Cornwall, and the effect of technological developments upon the character of slags. Unpublished $\mathrm{PhD}$ thesis, University of Bradford. Available at: http://hdl.handle.net/10454/4906

Matthews, S.G., forthcoming . At world's end: the Channel Bronze Age and the emergence and limits of the Atlantic complex, in: Lehoërff, A. (Ed.), Beyond Frontiers: Travel, exchange and communication from the fourth to the beginning of the first millennium BC in Europe. International conference of "Boat 1550 BC" project, Boulogne-sur-Mer (France), 3-5 October 2012. Oxbow, Oxford.

Meharg, A.A., Edwards, K.J., Schofield, J.E., Raab, A., Feldmann, J., Moran, A., Bryant, C.L., Thornton, B., Dawson, J.J.C., 2012. First comprehensive peat depositional records for tin, lead and copper associated with the antiquity of Europe's largest cassiterite deposits. J. Archaeol. Sci. 39 (3), 717-727. 
Memet, J.B., 2014. The corrosion of metallic artefacts in seawater: descriptive analysis, in: Dillmann, P., Beranger, G., Piccardo, P., Matthiessen, H. (Eds.) Corrosion of Metallic Heritage Artefacts: Investigation, conservation and prediction for long-term behaviour. European Federation of Corrosion Publication 48. Woodhead, Cambridge, pp. 152-169.

Merideth, C., 1998. An Archaeometallurgical Survey for Ancient Tin Mines and Smelting Sites in Spain and Portugal: Mid-Central Western Iberian Geographical Region 1990-1995. BAR International Series 714. Archaeopress, Oxford.

Miles, H., 1975. Barrows on the St. Austell Granite. Cornish Archaeol. 14, 5-81.

Möslein, S., Rieder, K.H., 1998. Zinnperlen aus einem frühbronzezeitlichen Grab von Buxheim, Landkreis Eichstätt, Oberbayern. Das Archäeologische Jahr in Bayern 1997, $68-70$.

Muckelroy, K., 1980. Two Bronze Age cargoes in British waters. Antiquity 54,100-109.

Muckelroy, K., 1981. Middle Bronze Age trade between Britain and Europe: a maritime perspective. Proc. Prehist. Soc. 47, 275-298.

Muhly, J.D., 1985. Sources of tin and the beginnings of bronze metallurgy. Am. J. Archaeol. 89 (2), 275-291.

Muhly, J.D., 1993. Early Bronze Age tin and the Taurus, Am. J. Archaeol. 97 (2), 239-253.

Needham, S., forthcoming. Transmanche in the Penard/Rosnoën stage wearing the same sleeve or keeping at arm's length? in: Lehoërff, A. (Ed.), Beyond Frontiers: Travel, exchange and communication from the fourth to the beginning of the first millennium BC in Europe. International conference of "Boat 1550 BC” project, Boulogne-sur-Mer (France), 3-5 October 2012. Oxbow, Oxford.

Needham, S., Giardino, C., 2008. From Sicily to Salcombe: A Mediterranean Bronze Age object from British coastal waters. Antiquity 82, 60-72.

Needham, S., Parham, D., Frieman, C.J., 2013. Claimed by the Sea: Salcombe, Langdon Bay, and other marine finds of the Bronze Age, CBA research report 173. Council for British Archaeology, York.

Nezafati, N., Pernicka, E., Momenzadeh, M., 2009. Introduction of the Deh Hosein ancient tin-copper mine, Western Iran: Evidence from geology, archaeology, geochemistry and lead isotope data. TÜBA-Ar 12, 223-236.

Niederschlag, E., Pernicka, E., Seifert, Th., Bartelheim, M., 2003. The determination of lead isotope ratios by multiple collector ICP-MS: A case study of Early Bronze Age artefacts and their possible relation with ore deposits of the Erzgebirge. Archaeometry 45(1), 61 100. 
Nielsen, E.H., 2014. A Late Bronze Age tin ingot from Sursee-Gammainseli (Kt. Luzern). Archäologisches Korrespondenzblatt 44 (2), 177-193.

Northover, J.P., 2010. Metal analysis of cauldrons and buckets, in: Gerloff, S. Atlantic Cauldrons and Buckets of the Late Bronze and Early Iron Ages in Western Europe: with a review of comparable vessels from Central Europe and Italy. Prähistorische Bronzefunde II, 18. Steiner, Stuttgart, pp. 352-365.

Northover, P., 2013. Metal analyses, in: Needham, S., Parham, D., Frieman, C.J., Claimed by the Sea: Salcombe, Langdon Bay, and other marine finds of the Bronze Age, CBA research report 173. Council for British Archaeology, York, pp. 101-112.

Northover, P., Gillis C., 1999. Questions in the analysis of ancient tin, in: Young, S.M.M., Pollard, A.M., Budd, P., Ixer, R.A. (Eds.), Metals in Antiquity, BAR International Series 792. Archaeopress, Oxford, pp. 78-85.

O’Brien, W., 2014. Prehistoric Copper Mining in Europe: 5500-500 BC. Oxford University Press, Oxford.

Pare, C.F.E., 1999. Weights and weighing in Bronze Age Central Europe, in: Eliten in der Bronzezeit: Ergebnisse zweier Kolloquien in Mainz und Athen (Römisch-Germanisches Zentralmuseum, Monographien 43). Verlag des Römisch-Germanischen Zentralmuseums, Mainz, pp. 421-514.

Pare, C.F.E., 2000. Bronze and the Bronze Age, in: Pare, C.F.E. (Ed), Metals Make the World Go Round: The Supply and Circulation of Metals in Bronze Age Europe. Oxbow, Oxford, pp. 1-38.

Pare, C.F.E., 2013. Weighing, Commodification and Money, in Fokkens, H., Harding, A.F., The Oxford Handbook of the European Bronze Age. Oxford University Press, Oxford, pp. 508-527.

Pearce, S., 1983. The Bronze Age Metalwork of South Western Britain. BAR British Series 120. Archaeopress, Oxford.

Penhallurick, R. D., 1986. Tin in Antiquity: its Mining and Trade throughout the Ancient World with Particular Reference to Cornwall. Institute of Metals, London.

Pernicka, E., 1990. Gewinnung und Verbreitung der Metalle in prähistorischer Zeit. Jahrbuch des Römisch Germanischen Zentralmuseums Mainz 37 (1/2), 21-129.

Pernicka, E., 1998. Die Ausbreitung der Zinnbronze im 3. Jahrtausend, in: Hänsel, B. (Ed.), Mensch und Umwelt in der Bronzezeit Europas. Abschlusstagung Die Bronzezeit: Das erste goldene Zeitalter Europas, Berlin 1997. Oetker-Voges Verlag, Kiel, pp. 135-147. 
Pigott, V.C., 2011. Sources of tin and the tin trade in Southwest Asia: the results of recent research and their importance to current understanding, in: Betancourt, P.P., Ferrence, S.C. (Eds.), Metallurgy: Understanding How, Learning Why: Studies in honor of James D. Muhly. Prehistory Monographs 29. INSTAP Academic Press, Philadelphia, pp. 267-285.

Pulak, C.M., 2000a. The copper and tin ingots from the Late Bronze Age shipwreck at Uluburun, in: Yalçin, Ü. (Ed.), Anatolian Metal I, Der Anschnitt 13. Deutschen BergbauMuseums, Bochum, pp. 137-157.

Pulak, C.M., 2000b. The balance weights from the Late Bronze Age shipwreck at Uluburun, in: Pare, C.F.E. (Ed.), Metals Make the World Go Round. The Supply and Circulation of Metals in Bronze Age Europe. Oxbow, Oxford, 247-266.

Pulak, C.M., 2010. Uluburun Shipwreck, in: Cline, E.H. (Ed.), The Oxford Handbook of the Bronze Age Aegean (ca. 3000-1000 BC). Oxford University Press, Oxford, pp. 862-876.

Rahmstorf, L., 2010. The concept of weighing during the Bronze Age in the Aegean, the Near East and Europe, in: Morley, I., Renfrew, C. (Eds.), The Archaeology of Measurement: Comprehending Heaven, Earth and Time in Ancient Societies. Cambridge University Press, Cambridge, pp. 88-105.

Roberts, B.W., Thornton, C.P. (Eds.), 2014. Archaeometallurgy in Global Perspective: Methods and Syntheses. Springer, New York etc.

Robinson, G., 2013. 'A Sea of Small Boats': places and practices on the prehistoric seascape of western Britain. Internet Archaeol. 34. http://dx.doi.org/10.11141/ia.34.2

Roden, C., 1985. Montanarchäologische Quellen des ur- und frühgeschichtlichen Zinnerzbergbaus in Europa. Der Anschnitt 37 (2/3), 50-80.

Rodríguez Díaz, A., Pavón Soldevila, I., Duque Espino, D.M., Ponce de León Iglesias, M., Hunt Ortiz, M.A., Merideth, C., 2013. La explotación tartésica de la casiterita entre los ríos Tajo y Guadiana: San Cristóbal de Logrosán (Cáceres). Trabajos de Prehistoria 70 (1), 95-113.

Roscio, M., Delor, J-P., Muller, F., 2011. Late Bronze Age graves with weighing equipment from eastern France: the example of Migennes "le Petit Moulin" (dép. Yonne), burial no. 298. Archäologisches Korrespondenzblatt 41 (2), 173-187.

Salter, C., 1997. A note on the tin slags from Caerloggas Down, Cornwall, and the Upper Merrivale blowing house, Devon, in: Budd, P., Gale, D. (Eds.), Prehistoric Extractive Metallurgy in Cornwall: Proceedings of a one day conference held at the Camborne 
School of Mines, Pool, Redruth, Cornwall, 11th July 1992. Cornwall Archaeology Unit, Truro, pp. 45-50.

Selimkhanov, I.R., 1978. Ancient tin objects of the Caucasus and the results of their analyses, in Franklin, A.D., Olin, J.S., Wertime, T.A. (Eds.), The Search for Ancient Tin. Smithsonian Institution, Washington, pp. 53-58.

Shell, C.A., 1979. The early exploitation of tin deposits in south-west England, in: Ryan, M. (Ed.), The Origins of Metallurgy in Atlantic Europe: Proceedings of the Fifth Atlantic Colloquium, Dublin, 30th March to 4th April 1978. Stationery Office, Dublin, pp. 251263.

Sherratt, A., 1993. What would a Bronze-Age World System look like? Relations between temperate Europe and the Mediterranean in later prehistory. J. Eur. Archaeol. 1 (2), 1-57.

Standish, C. D., Dhuime, B., Chapman, R.J., Coath, C., Hawkesworth, C.J., Pike, A.W.G., 2014. The genesis of gold mineralisation hosted by orogenic belts: A lead isotope investigation of Irish gold deposits. Chem. Geol. 378-379, 40-51.

Standish, C.D., Dhuime, B., Hawkesworth, C.J., Pike, A.W.G., 2015. A non-local source of Irish Chalcolithic and Early Bronze Age gold. Proc. Prehist. Soc. 81, 149-177.

Stöllner, T., Samaschev, Z., Berdenov, S., Cierny,J., Doll, M., Garner, J., Gontscharov, A., Gorelik, A., Hauptmann, A., Herd, R., Kusch, G.A., Merz, V., Riese, T., Sikorski, B., Zickgraf, B., 2011. Tin from Kazakhstan - steppe tin for the West, in: Yalçın, Ü. (Ed.), Anatolian Metal V. Der Anschnitt 24._Deutsches Bergbau-Museum, Bochum, pp. 231252.

Stos-Gale, Z. A., Gale, N. H., Bass, G., Pulak, C., Galili, E., Sharvit, J., 1998. The copper and tin ingots of the Late Bronze Age Mediterranean: New scientific evidence, in: Igaki, K. (Ed), Proceedings : the Fourth International Conference on the Beginning of the Use of Metals and Alloys (BUMA-IV), May 25-27, 1998, Matsue, Shimane, Japan. Japan Institute of Metals, Sendai, pp. 115-126.

Strachan, D., 2010. Carpow in Context: A Late Bronze Age Logboat from the Tay. Society of Antiquaries of Scotland, Edinburgh.

SWAG (South West Archaeological Group), 1993. Tin ingot wreck site, the British Sub-Aqua Jubilee Trust 1993 Award Report. Site Ref. No. 1992-2.

Thorndycraft, V.R., Pirrie, D., Brown, A.G., 2004. Alluvial records of medieval and prehistoric tin mining on Dartmoor, southwest England. Geoarchaeology 19 (3), 219236.

Timberlake, S., 1994. An experimental tin smelt at Flag Fen. Hist. Metall. 28 (1), 122-128. 
Turgoose, S., 1985. The corrosion of lead and tin: before and after excavation, in: Miles, G., Pollard, S. (Eds.), Lead and Tin Studies in Conservation and Technology: Papers presented at a UKIC conference "Lead and Tin: a Re-consideration" (Oxford, 1983), UKIC Occasional Papers 3. The United Kingdom Institute for Conservation, London, pp.15-26.

Tylecote, R.F., 1975. Analysis of slag fragments, in: Miles, H., Barrows on the St. Austell Granite, Cornwall. Cornish Archaeol. 14, 35-38.

Tylecote, R.F., 1986. The Prehistory of Metallurgy in the British Isles, Institute of Metals, London.

Uckelmann, M., 2012. Die Schilde der Bronzezeit in Nord-, West- und Zentraleuropa. Prähistorische Bronzefunde III: 4. Steiner, Stuttgart.

Valera, R. G., Valera, P. G., 2003. Tin in the Mediterranean area: history and geology, in: Giumlia-Mair, A., Lo Schiavo, F. (Eds.), The Problem of Early Tin. Acts of the XIVth UISPP Congress, University of Liège, Belgium, 2-8 September 2001. BAR International Series 1199. Archaeopress, Oxford, pp. 3-14.

Van de Noort, R., 2006. Argonauts of the North Sea - a social maritime archaeology for the 2nd millennium BC. Proc. Prehist. Soc. 72, 267-287.

Van de Noort, R., Cumby, B., Blue, L., Harding, A., Hurcombe, L., Hansen, T.M., Wetherelt, A., Wittamore, J., Wyke, A., 2014. Morgawr: an experimental Bronze Age-type sewnplank craft based on the Ferriby boats. Int. J. Naut. Archaeol. 43 (2), 292-313.

Wang, Q. 2016. Chapter 6. Metal analysis, in: Baldwin, A. Joy, J., A Celtic Feast: The Iron Age Cauldrons from Chiseldon, Wiltshire. Research Publication 203. British Museum Press (in press).

Wang, Q., Uckelmann, M., Robert, B.W., La Niece, S., forthcoming. Technical Studies of the British Bronze Age Shields in the British Museum Collection, in: preprint of ICOMCC Metal 2016.

Warner, R., Moles, N., Chapman, R., 2010a. Evidence for Early Bronze Age tin and gold extraction in the Mourne Mountains, County Down. J. Mining Heritage Trust Ireland 10, 29-36.

Warner, R., Moles, N., Chapman R., Cahill, M., 2010b. The Mournes: a source of early Bronze Age tin and gold. Archaeol. Ireland 24 (4), 18-21.

Woodward, A., Hunter, J., 2015. Ritual in Early Bronze Age Grave Goods: An examination of ritual and dress equipment from Chalcolithic and Early Bronze Age graves in England. Oxbow, Oxford. 
Wright, E.V., Hedges, R., Bayliss, A., Van de Noort, R., 2001. New AMS radiocarbon dates for the North Ferriby boats - a contribution to dating prehistoric seafaring in northwestern Europe. Antiquity 75, 726-734.

Yener, K.A., Vandiver, P.B., 1993. Reply to J.D. Muhly, "Early Bronze Age tin and the Taurus". Am. J. Archaeol. 97 (2), 255-264.

Yener, K.A., Kulakoğlu, F., Yazgan, E., Kontani, R., Hayakawa, Y.S., Lehner, J.W., Dardeniz, G., Öztürk, G., Johnson, M., Kaptan, E., Hacar, A., 2015. New tin mines and production sites near Kültepe in Turkey: a third-millennium BC highland production model. Antiquity 89, 596-612. 
Table 1. Weight and dimensions of the tin ingots studied

\begin{tabular}{|c|c|c|c|c|c|}
\hline Reg. No & shape & Weight (g) & length (mm) & width (mm) & thickness (mm) \\
\hline \multicolumn{6}{|l|}{ Salcombe } \\
\hline 2010,8032.295 & round and plano-convex & 9166 & 228 & 219 & 114 \\
\hline 2010,8032.296 & oval with plano-convex profile & 255 & 92 & 62 & 30 \\
\hline $2010,8032.297$ & irregular & 131 & 87 & 55 & 23 \\
\hline $2010,8032.298$ & irregular & 25 & 37 & 30 & 12 \\
\hline 2010,8032.299 & irregular, flat & 202 & 93 & 64 & 19 \\
\hline $2010,8032.300$ & oval with plano-convex profile & 366 & 125 & 64 & 32 \\
\hline $2010,8032.301$ & irregular, flat & 377 & 122 & 92 & 20 \\
\hline $2010,8032.302$ & irregular, flat & 21 & 37 & 24 & 7 \\
\hline $2010,8032.303$ & irregular & 14 & 10 & 22 & 7 \\
\hline $2010,8032.304$ & & 258 & 108 & 58 & 20 \\
\hline $2010,8032.305$ & irregular & 287 & 96 & 77 & 32 \\
\hline $2010,8032.306$ & folded & 329 & 90 & 66 & 46 \\
\hline $2010,8032.307$ & irregular & 16 & 38 & 24 & 10 \\
\hline $2010,8032.308$ & irregular & 37 & 43 & 37 & 11 \\
\hline $2010,8032.309$ & oval with plano-convex profile & 314 & 105 & 67 & 21 \\
\hline $2010,8032.310$ & irregular with plano-convex profile & 359 & 111 & 82 & 17 \\
\hline $2010,8032.311$ & irregular, flat & 196 & 118 & 70 & 7 \\
\hline $2010,8032.312$ & relatively flat, folded over & 517 & 135 & 89 & 31 \\
\hline $2010,8032.313$ & oval with plano-convex profile & 1003 & 165 & 98 & 34 \\
\hline $2010,8032.314$ & oval with plano-convex profile & 184 & 81 & 52 & 23 \\
\hline $2010,8032.315$ & oval with plano-convex profile & 682 & 129 & 66 & 36 \\
\hline $2010,8032.316$ & oval with plano-convex profile & 1257 & 185 & 10 & 25 \\
\hline $2010,8032.317$ & circular with plano-convex profile & 600 & 95 & 90 & 20 \\
\hline $2010,8032.318$ & oval with plano-convex profile & 368 & 86 & 72 & 28 \\
\hline $2010,8032.320$ & roundish with flat base & 1194 & 160 & 140 & 20 \\
\hline $2010,8032.321$ & roundish with flat base & 169 & 64 & 50 & 24 \\
\hline
\end{tabular}




\begin{tabular}{|c|c|c|c|c|c|}
\hline $2010,8032.322$ & irregular & 116 & 60 & 56 & 24 \\
\hline $2010,8032.323$ & roundish & 8 & 12 & 8 & \\
\hline $2010,8032.329$ & possible oval die mark on one side & 5 & 18 & 14 & 6 \\
\hline 2013,8032.1 & oval with plano-convex profile & 645 & 120 & 90 & 20 \\
\hline $2013,8032.2$ & oval & 11 & 31 & 21 & 7 \\
\hline $2013,8032.3$ & oval, folded over & 160 & 80 & 45 & 28 \\
\hline $2013,8032.4$ & irregular & 19 & 52 & 34 & 4 \\
\hline $2013,8032.5$ & thin, largely corrosion product & 4 & 4 & 3 & 4 \\
\hline $2013,8032.6$ & oval & 19 & 45 (diameter) & & 5 \\
\hline $2013,8032.7$ & irregular & 97 & 66 & 50 & 16 \\
\hline $2013,8032.8$ & plano-convex & 97 & 78 & 45 & 21 \\
\hline 2013,8032.9 & plano-convex & 675 & 112 & 83 & 23 \\
\hline $2013,8032.10$ & relatively flat & 136 & 95 & 48 & 8 \\
\hline $2013,8032.11$ & & 1147 & 109 & 95 & 67 \\
\hline \multicolumn{6}{|l|}{ Erme Estuary } \\
\hline $2013,8031.1$ & plano-convex & 789 & 110 & 120 & 30 \\
\hline $2013,8031.2$ & plano-convex & 669 & 135 & 115 & 31 \\
\hline
\end{tabular}


Table 2. Bulk chemical composition of tin ingots determined by ICP-AES and ICP-MS (wt.\% for tin and $\mu \mathrm{g} \mathrm{g}^{-1}$ for other elements)

\begin{tabular}{|c|c|c|c|c|c|c|c|c|c|c|c|c|c|c|c|c|c|c|}
\hline Sample & Sn & $\mathrm{S}$ & Mn & $\mathrm{Fe}$ & Co & $\mathrm{Ni}$ & $\mathrm{Cu}$ & $\mathrm{Zn}$ & As & $\mathrm{Ag}$ & In & $\mathrm{Sb}$ & $\mathrm{W}$ & $\mathrm{Au}$ & $\mathrm{Pb}$ & $\mathrm{Bi}$ & $\mathrm{U}$ & Total \\
\hline & $\%$ & & & & & & & $\mu \mathrm{g} \mathrm{g}^{-1}$ & & & & & & & & & & $\%$ \\
\hline \multicolumn{19}{|l|}{ Salcombe } \\
\hline $2010,8032.295$ & 94.1 & 538 & 4.2 & 2065 & $<8$ & $<10$ & 3.5 & 18.1 & 7.15 & 0.16 & 13.9 & 6.55 & $<0.5$ & 2.15 & 12.0 & 13.4 & $<0.07$ & 94.4 \\
\hline $2010,8032.296$ & 100.3 & $<44$ & $<1.8$ & 86.2 & $<8$ & $<10$ & 7.2 & $<2$ & 35.0 & $<0.1$ & 21.6 & 46.4 & $<0.5$ & $<0.5$ & 13.8 & 31.3 & $<0.07$ & 100.3 \\
\hline $2010,8032.297$ & 98.9 & $<42$ & 3.6 & 52.1 & $<8$ & $<10$ & 2.2 & $<2$ & 19.5 & $<0.1$ & 30.1 & 64.0 & $<0.5$ & $<0.5$ & 26.4 & 83.2 & $<0.07$ & 98.9 \\
\hline $2010,8032.298$ & 99.4 & $<113$ & $<1.8$ & 126 & $<8$ & $<10$ & $<1.2$ & $<6$ & 14.3 & $<0.1$ & 29.6 & 90.0 & $<0.5$ & $<0.5$ & 27.0 & 79.4 & $<0.07$ & 99.5 \\
\hline $2010,8032.299$ & 99.5 & $<<5$ & $<1.8$ & 88.4 & $<8$ & $<10$ & $<1.2$ & $<2$ & 17.4 & $<0.1$ & 31.1 & 65.2 & $<0.5$ & $<0.5$ & 26.7 & 83.2 & $<0.07$ & 99.5 \\
\hline $2010,8032.300$ & 96.0 & $<42$ & $<1.8$ & 55.3 & $<8$ & $<10$ & $<1.2$ & $<2$ & 10.1 & 0.10 & 9.87 & 9.13 & $<0.5$ & $<0.5$ & 7.08 & 4.50 & $<0.07$ & 96.0 \\
\hline $2010,8032.301$ & 100.8 & $<54$ & 7.1 & 99.4 & $<8$ & $<10$ & $<1.2$ & $<6$ & 16.1 & 0.43 & 33.5 & 76.8 & $<0.5$ & $<0.5$ & 30.5 & 76.7 & $<0.07$ & 100.8 \\
\hline $2010,8032.302$ & 100.9 & $<185$ & $<1.8$ & 31.4 & $<8$ & $<10$ & 8.1 & 10.0 & 8.97 & $<0.1$ & 17.9 & 16.6 & $<0.5$ & $<0.5$ & 8.86 & 5.78 & $<0.07$ & 100.9 \\
\hline $2010,8032.303$ & 94.6 & $<113$ & 2.9 & 68.7 & $<8$ & $<10$ & 6.7 & $<6$ & 5.99 & $<0.1$ & 11.9 & 12.9 & $<0.5$ & $<0.5$ & 6.32 & 4.61 & $<0.07$ & 94.7 \\
\hline $2010,8032.304$ & 97.4 & $<40$ & $<1.8$ & 80.2 & $<8$ & $<10$ & 4.4 & $<2$ & 21.6 & $<0.1$ & 5.11 & 4.10 & $<0.5$ & $<0.5$ & 12.8 & 32.7 & $<0.07$ & 97.4 \\
\hline $2010,8032.305$ & 96.7 & 562 & 6.0 & 77.2 & $<8$ & $<10$ & 5.9 & $<6$ & 19.3 & 1.34 & 13.2 & 6.76 & $<0.5$ & $<0.5$ & 19.1 & 33.7 & 0.11 & 96.8 \\
\hline $2010,8032.306$ & 99.6 & $<130$ & $<1.8$ & 43.8 & $<8$ & $<10$ & $<1.2$ & $<6$ & 6.59 & $<0.1$ & 12.5 & 12.7 & $<0.5$ & $<0.5$ & 6.16 & 4.60 & $<0.07$ & 99.6 \\
\hline $2010,8032.307$ & 97.9 & $<58$ & $<1.8$ & 79.8 & 8.1 & $<10$ & 2.8 & $<6$ & 81.2 & $<0.1$ & 33.2 & 145 & $<0.5$ & $<0.5$ & 60.7 & 120 & $<0.07$ & 97.9 \\
\hline $2010,8032.308$ & 99.2 & $<53$ & $<1.8$ & 87.4 & 8.1 & $<10$ & 24.4 & $<6$ & 86.0 & $<0.1$ & 36.8 & 151 & $<0.5$ & $<0.5$ & 70.4 & 128 & 0.09 & 99.2 \\
\hline $2010,8032.309$ & 99.8 & $<58$ & $<1.8$ & 58.4 & $<8$ & $<10$ & 83.1 & $<6$ & 8.50 & $<0.1$ & 17.3 & 15.1 & $<0.5$ & $<0.5$ & 6.77 & 4.45 & $<0.07$ & 99.8 \\
\hline $2010,8032.310$ & 96.8 & $<104$ & 16.8 & 1461 & $<8$ & $<10$ & 5.3 & $<6$ & 7.76 & $<0.1$ & 13.4 & 15.8 & $<0.5$ & $<0.5$ & 5.25 & 4.66 & $<0.07$ & 97.0 \\
\hline $2010,8032.311$ & 99.9 & $<174$ & $<1.8$ & 70.1 & $<8$ & $<10$ & $<1.2$ & $<6$ & 6.64 & $<0.1$ & 15.5 & 11.07 & $<0.5$ & $<0.5$ & 5.03 & 4.97 & $<0.07$ & 99.9 \\
\hline $2010,8032.312$ & 99.2 & $<36$ & $<1.8$ & 60.7 & $<8$ & $<10$ & 28.8 & $<2$ & 9.55 & $<0.1$ & 11.0 & 9.15 & $<0.5$ & $<0.5$ & 5.84 & 4.56 & $<0.07$ & 99.2 \\
\hline $2010,8032.313$ & 99.2 & $<95$ & $<1.8$ & 131.2 & $<8$ & $<10$ & $<1.2$ & $<6$ & 8.17 & $<0.1$ & 13.9 & 289 & $<0.5$ & $<0.5$ & 4.97 & 3.22 & $<0.07$ & 99.3 \\
\hline $2010,8032.314$ & 100.1 & $<66$ & $<1.8$ & 188.8 & $<8$ & $<10$ & $<1.2$ & $<6$ & 8.22 & $<0.1$ & 16.6 & 12.0 & $<0.5$ & $<0.5$ & 8.69 & 4.48 & $<0.07$ & 100.1 \\
\hline $2010,8032.315$ & 97.9 & $<41$ & $<1.8$ & 124.8 & $<8$ & $<10$ & 2.9 & $<6$ & 11.9 & $<0.1$ & 10.7 & 5.55 & $<0.5$ & $<0.5$ & 11.3 & 46.0 & $<0.07$ & 97.9 \\
\hline $2010,8032.316$ & 101.1 & $<44$ & $<1.8$ & 54.5 & $<8$ & $<10$ & 1.8 & 19.2 & 7.53 & $<0.1$ & 20.2 & 8.68 & $<0.5$ & $<0.5$ & 12.8 & 6.50 & $<0.07$ & 101.1 \\
\hline $2010,8032.317$ & 100.6 & $<46$ & $<1.8$ & 431 & $<8$ & $<10$ & 1.8 & $<6$ & 8.27 & $<0.1$ & 22.0 & 277 & $<0.5$ & $<0.5$ & 8.34 & 3.20 & $<0.07$ & 100.7 \\
\hline
\end{tabular}




\begin{tabular}{|c|c|c|c|c|c|c|c|c|c|c|c|c|c|c|c|c|c|c|}
\hline $2010,8032.318$ & 100.0 & $<64$ & 11.0 & 113 & $<8$ & $<10$ & 5.1 & 13.6 & 19.3 & $<0.1$ & 12.7 & 6.31 & $<0.5$ & $<0.5$ & 17.0 & 31.0 & $<0.07$ & 100.1 \\
\hline $2010,8032.320$ & 99.2 & $<29$ & $<1.8$ & 48.9 & $<8$ & $<10$ & $<1.2$ & $<6$ & 12.5 & $<0.1$ & 29.9 & 233 & $<0.5$ & $<0.5$ & 8.37 & 3.60 & $<0.07$ & 99.2 \\
\hline $2010,8032.321$ & 100.0 & $<30$ & $<1.8$ & 73.4 & $<8$ & $<10$ & 3.8 & $<6$ & 8.85 & $<0.1$ & 14.9 & 12.2 & $<0.5$ & $<0.5$ & 10.4 & 4.32 & $<0.07$ & 100.0 \\
\hline $2010,8032.322$ & 101.4 & $<44$ & $<1.8$ & 269 & 9.3 & $<10$ & $<1.2$ & $<6$ & 34.4 & $<0.1$ & 40.3 & 140 & $<0.5$ & $<0.5$ & 30.0 & 49.2 & $<0.07$ & 101.5 \\
\hline $2010,8032.323$ & 100.3 & $<78$ & $<1.8$ & 162 & $<8$ & 24.0 & 2742 & $<6$ & 29.0 & 0.41 & 6.71 & 25.4 & $<0.5$ & 2.36 & 87.2 & 11.5 & $<0.07$ & 100.6 \\
\hline $2010,8032.329$ & 98.6 & 117 & 4.0 & 251 & $<8$ & $<10$ & 286 & 18.8 & 21.6 & 0.61 & 34.9 & 9.69 & $<0.5$ & 0.70 & 7.19 & 15.2 & 0.18 & 98.6 \\
\hline $2013,8032.1$ & 98.0 & $<36$ & 4.0 & 103 & $<8$ & $<10$ & 19.8 & $<2$ & 13.2 & $<0.1$ & 7.08 & 13.3 & $<0.5$ & $<0.5$ & 13.4 & 6.54 & $<0.07$ & 98.0 \\
\hline $2013,8032.2$ & 97.4 & $<44$ & $<1.8$ & 100 & $<8$ & $<10$ & 4.7 & $<2$ & 16.5 & $<0.1$ & 26.7 & 66.5 & $<0.5$ & $<0.5$ & 18.4 & 83.1 & $<0.07$ & 97.4 \\
\hline $2013,8032.3$ & 96.6 & $<41$ & 2.0 & 143 & $<8$ & $<10$ & 15.7 & 2.3 & 9.76 & $<0.1$ & 11.2 & 9.73 & $<0.5$ & $<0.5$ & 92.3 & 5.17 & $<0.07$ & 96.7 \\
\hline $2013,8032.4$ & 93.0 & 82 & 12.4 & 462 & $<8$ & $<10$ & 54.5 & $<2$ & 7.64 & 0.14 & 4.47 & 11.5 & $<0.5$ & $<0.5$ & 4.99 & 5.02 & 0.17 & 93.1 \\
\hline $2013,8032.6$ & 94.1 & $<46$ & 5.2 & 575 & $<8$ & $<10$ & 6.8 & $<2$ & 7.79 & $<0.1$ & 5.35 & 9.72 & 0.91 & $<0.5$ & 4.09 & 5.46 & 0.11 & 94.2 \\
\hline $2013,8032.7$ & 97.0 & 60 & $<1.8$ & 70.3 & $<8$ & $<10$ & 32.5 & $<2$ & 11.1 & $<0.1$ & 4.80 & 8.35 & 0.65 & $<0.5$ & 14.7 & 5.65 & $<0.07$ & 97.0 \\
\hline $2013,8032.8$ & 97.0 & $<42$ & $<1.8$ & 122 & $<8$ & $<10$ & 14.5 & $<2$ & 58.9 & 0.15 & 24.8 & 79.9 & $<0.5$ & $<0.5$ & 36.5 & 65.3 & $<0.07$ & 97.0 \\
\hline $2013,8032.9$ & 97.1 & 48 & $<1.8$ & 735 & $<8$ & $<10$ & 26.9 & 16.4 & 45.0 & $<0.1$ & 14.2 & 101 & $<0.5$ & $<0.5$ & 16.7 & 26.5 & $<0.07$ & 97.2 \\
\hline $2013,8032.10$ & 96.5 & 92 & 5.9 & 538 & $<8$ & $<10$ & 3.6 & $<2$ & 9.65 & $<0.1$ & 11.6 & 10.8 & 0.87 & $<0.5$ & 5.87 & 4.76 & $<0.07$ & 96.6 \\
\hline $2013,8032.11$ & 98.7 & 293 & $<1.8$ & 143 & $<8$ & $<10$ & 66.2 & 11.3 & 17.3 & $<0.1$ & 25.4 & 68.6 & 0.73 & $<0.5$ & 31.6 & 75.7 & $<0.07$ & 98.8 \\
\hline Min & 93.0 & $<29$ & $<1.8$ & 31.4 & $<8$ & $<10$ & $<1.2$ & & 5.99 & $<0.1$ & 4.47 & 4.1 & $<0.5$ & $<0.5$ & 4.09 & & $<0.07$ & \\
\hline $\operatorname{Max}$ & 101.4 & 562 & 16.8 & 2065 & 9.3 & 24.0 & 2742 & 19.2 & 86 & 1.34 & 40.3 & 289 & 0.91 & 2.36 & 92.3 & & 0.18 & \\
\hline Mean & 98.3 & & & 244 & & & $89^{*}$ & & 19.2 & & 18.4 & 55.3 & & & & & & \\
\hline Median & 98.9 & & & 100 & & & $5^{*}$ & & 11.9 & & 14.9 & 13.3 & & & & & & \\
\hline
\end{tabular}

\section{Erme Estuary}

\begin{tabular}{|c|c|c|c|c|c|c|c|c|c|c|c|c|c|c|c|c|c|c|}
\hline $2013,8031.1$ & 94.3 & 123 & 11.4 & 2288 & $<8$ & $<10$ & 37.3 & 4.0 & 15.4 & 0.111 & 20.9 & 62.6 & 13.7 & $<0.5$ & 12.5 & 34.4 & 0.08 & 94.6 \\
\hline 2013 & 98.1 & $<47$ & $<1.8$ & 107 & 32.7 & 60.1 & 22.6 & $<2$ & 39.6 & 0.222 & 16.8 & 13.9 & 0.82 & 1.03 & 4.63 & 1680 & $<0.07$ & 98.3 \\
\hline
\end{tabular}

Note: * Estimated as being equal to or lower than this value. 